\title{
Methanogenic food web in the gut contents of methane-emitting earthworm Eudrilus eugeniae from Brazil
}

\author{
Kristin Schulz ${ }^{1,5}$, Sindy Hunger ${ }^{1}$, George G Brown ${ }^{2}$, Siu M Tsai ${ }^{3}$, Carlos C Cerri ${ }^{3}$, \\ Ralf Conrad ${ }^{4}$ and Harold L Drake ${ }^{1}$ \\ ${ }^{1}$ Department of Ecological Microbiology, University of Bayreuth, Bayreuth, Germany; ${ }^{2}$ Embrapa Florestas, \\ Colombo, Brazil; ${ }^{3}$ CENA-USP, Center for Nuclear Energy in Agriculture, University of São Paulo, São Paulo, \\ Brazil and ${ }^{4}$ Max-Planck-Institute for Terrestrial Microbiology, Marburg, Germany
}

\begin{abstract}
The anoxic saccharide-rich conditions of the earthworm gut provide an ideal transient habitat for ingested microbes capable of anaerobiosis. It was recently discovered that the earthworm Eudrilus eugeniae from Brazil can emit methane $\left(\mathrm{CH}_{4}\right)$ and that ingested methanogens might be associated with this emission. The objective of this study was to resolve trophic interactions of bacteria and methanogens in the methanogenic food web in the gut contents of $E$. eugeniae. RNA-based stable isotope probing of bacterial 16S rRNA as well as mcrA and mrtA (the alpha subunit of methyl-CoM reductase and its isoenzyme, respectively) of methanogens was performed with $\left[{ }^{13} \mathrm{C}\right]-$ glucose as a model saccharide in the gut contents. Concomitant fermentations were augmented by the rapid consumption of glucose, yielding numerous products, including molecular hydrogen $\left(\mathrm{H}_{2}\right)$, carbon dioxide $\left(\mathrm{CO}_{2}\right)$, formate, acetate, ethanol, lactate, succinate and propionate. Aeromonadaceaeaffiliated facultative aerobes, and obligate anaerobes affiliated to Lachnospiraceae, Veillonellaceae and Ruminococcaceae were associated with the diverse fermentations. Methanogenesis was ongoing during incubations, and ${ }^{13} \mathrm{C}$-labeling of $\mathrm{CH}_{4}$ verified that supplemental $\left[{ }^{13} \mathrm{C}\right]$-glucose derived carbon was dissimilated to $\mathrm{CH}_{4}$. Hydrogenotrophic methanogens affiliated with Methanobacteriaceae and Methanoregulaceae were linked to methanogenesis, and acetogens related to Peptostreptoccocaceae were likewise found to be participants in the methanogenic food web. $\mathrm{H}_{2}$ rather than acetate stimulated methanogenesis in the methanogenic gut content enrichments, and acetogens appeared to dissimilate supplemental $\mathrm{H}_{2}$ to acetate in methanogenic enrichments. These findings provide insight on the processes and associated taxa potentially linked to methanogenesis and the turnover of organic carbon in the alimentary canal of methane-emitting $E$. eugeniae.
\end{abstract}

The ISME Journal (2015) 9, 1778-1792; doi:10.1038/ismej.2014.262; published online 23 January 2015

\section{Introduction}

Earthworms go mostly unnoticed because of their subsurface lifestyle. However, the propensity of earthworms to consume and transform their habitat has significant impact on terrestrial ecosystems and soil processes (Darwin, 1881; Lee, 1985; Edwards and Bohlen, 1996; Makeschin, 1997; Brown and James, 2006; Nechitaylo et al., 2010). For example, Lumbricus terrestris can consume the entire annual litter fall $\left(300 \mathrm{~g} \mathrm{~m}^{-2}\right)$ of forests it inhabits (Satchell, 1967). Earthworms can likewise be a dominant macrofauna

Correspondence: HL Drake, Department of Ecological Microbiology, University of Bayreuth, Dr Hans-Frisch-Str. 1-3, Bayreuth 95440, Germany.

E-mail: HLD@uni-bayreuth.de

${ }^{5}$ Current address: Department of Microbial Ecology, Netherlands Institute of Ecology (NIOO-KNAW), Wageningen $6708 \mathrm{AB}$, The Netherlands.

Received 29 July 2014; revised 28 November 2014; accepted 5 December 2014; published online 23 January 2015 of soil and up to 2000 individuals per square meter of soil have been recorded (Edwards and Bohlen, 1996). Assuming an average gut volume of approximately $250 \mathrm{~mm}^{3}$ (80 mm length $\times 1 \mathrm{~mm}^{2}$ radius $\left.\times \pi\right)$, this number of earthworms would theoretically yield approximately $500 \mathrm{ml}$ of gut contents per square meter of soil, illustrating that the alimentary canal of the earthworm can be an important component of soil.

The alimentary canal of the earthworm constitutes a mobile anoxic micro-compartment in aerated soils (Drake and Horn, 2007). The in situ conditions of the earthworm gut include anoxia, near neutral $\mathrm{pH}$, relatively low redox potentials and millimolar concentrations of monosaccharide equivalents in the aqueous phase (Horn et al., 2003; Drake and Horn, 2007; Wüst et al., 2009a). The high concentration of saccharides in the gut appears to be derived from the saccharide-rich mucus that is secreted in the alimentary canal for facilitating gut passage and digestion of the ingested matter (Lavelle, 1986; Barois, 1987, Edwards and Bohlen, 1996; Trigo et al., 1999; 
Brown et al., 2000). The in situ conditions of the gut stimulate ingested obligate anaerobes and facultative aerobes that promote diverse fermentations along the alimentary canal, and fermentation-derived molecular hydrogen $\left(\mathrm{H}_{2}\right)$ is emitted in vivo by earthworms (Karsten and Drake, 1995; Schmidt et al., 2001; Wüst et al., 2009a, 2011). Fermentation products in the gut may serve as substrates for soil-derived denitrifiers and be trophically linked to the in vivo emission of nitrous oxide $\left(\mathrm{N}_{2} \mathrm{O}\right)$ and dinitrogen $\left(\mathrm{N}_{2}\right)$ (Karsten and Drake, 1997; Matthies et al., 1999; Depkat-Jakob et al., 2013). In this regard, earthworms can contribute to the capacity of soils to emit nitrogenous gases (Karsten and Drake, 1997; Matthies et al., 1999; Rizhiya et al., 2007; Lubbers et al., 2011), and it has been postulated that the emission of $\mathrm{H}_{2}$ by earthworms might drive energy-dependent processes in soil such as the fixation of $\mathrm{N}_{2}$ or carbon dioxide $\left(\mathrm{CO}_{2}\right)$ (Wüst et al., 2009a). Soil iron is likewise subject to anaerobic redox transformations during gut passage (Wüst et al., 2009a). These findings illustrate that the alimentary canal of earthworms augments diverse anaerobic microbial activities that impact on the cycling of elements in soils.

Several studies have indicated that earthworms do not emit methane $\left(\mathrm{CH}_{4}\right)$ (Hornor and Mitchell, 1981; Karsten and Drake, 1995; Drake and Horn, 2007; Šustr and Šimek, 2009). It was therefore surprising that certain earthworms in Brazil, in particular Eudrilus eugeniae, were recently discovered to emit $\mathrm{CH}_{4}$ in vivo (Depkat-Jakob et al., 2012). $E$. eugeniae is an epigeic species that is native to certain African soils but is commonly used in vermicomposting in other countries, including Brazil (Martinez, 1998; Domínguez, 2004; Oboh et al., 2007). The emission of $\mathrm{CH}_{4}$ by E. eugeniae appeared to be linked to the ingested methanogens of the families Methanosarcinaceae, Methanobacteriaceae and Methanomicrobiaceae (Depkat-Jakob et al., 2012). We hypothesized that the capacity of E. eugeniae to emit $\mathrm{CH}_{4}$ is linked to diverse fermentations in the alimentary canal, and the main objective of this study was to resolve anaerobic processes and associated taxa that can potentially drive methanogenesis in the gut of E. eugeniae.

\section{Material and methods}

Earthworms

Adult earthworms of the species $E$. eugeniae (Eudrilidae) were obtained in May 2012 from the distributer Minhobox (Juiz de Fora, Minas Gerais, Brazil). Earthworms were $2.3 \pm 0.2 \mathrm{~g}$ and $11-20 \mathrm{~cm}$ in length. The gut passage time of adult specimens of E. eugeniae is approximately $6 \mathrm{~h}$ (Mba, 1988).

In vivo emission of $\mathrm{CH}_{4}$ Individual specimens of $E$. eugeniae were washed with sterile deionized water, dried by blotting with tissue paper, weighed and placed into sterile $160-\mathrm{ml}$ serum vials (one earthworm per replicate). Serum vials were sealed with butyl rubber septum stoppers and incubated for $5 \mathrm{~h}$ at room temperature in the dark. The gas phase was air.

\section{Gut content microcosms}

Earthworms were washed and exposed to ice-cold, sparkling mineral water. Gut content (approximately $25 \mathrm{~g}$ ) was squeezed out from approximately 100 earthworms while gassing with $100 \%$ argon to minimize exposure of the gut content to air (Depkat-Jakob et al., 2012). Gut content was kept under an anoxic atmosphere of $100 \%$ argon in sterile serum bottles and mixed to a 1:10 (w/v) dilution with sterile anoxic sodium phosphate buffer (Wüst et al., 2011). The gut content homogenate was distributed into nine sterile anoxic 160ml serum bottles that were crimp sealed with sterile butyl rubber stoppers and wrapped with tinfoil to minimize exposure to light; the gas phase was $100 \%$ argon. Each serum bottle contained 18-ml gut content homogenate (corresponding to approximately 1.8-g gut content) and was preincubated overnight in the dark at $25{ }^{\circ} \mathrm{C}$ to ensure that residual molecular oxygen $\left(\mathrm{O}_{2}\right)$ was consumed. Replicates of three serum bottles were treated with either $2 \mathrm{ml}$ of $100 \mathrm{~mm}\left[{ }^{12} \mathrm{C}\right]$-glucose (AppliChem GmbH, Darmstadt, Germany) or $2 \mathrm{ml}$ of $100 \mathrm{~mm}\left[{ }^{13} \mathrm{C}\right]$-glucose (Sigma-Aldrich Chemie GmbH, Munich, Germany; 99 atom $\%{ }^{13} \mathrm{C}$ ). Two milliliters of sterile anoxic water was added to three control bottles. Bottles were incubated in the dark at $25^{\circ} \mathrm{C}$. Samples were taken at different intervals after the addition of substrate with sterile syringes that had been flushed with sterile argon. Samples $(1 \mathrm{ml})$ for molecular analyses were preserved in 9-ml RNAlater RNA Stabilization Reagent (Qiagen, Hilden, Germany) and stored at $-20^{\circ} \mathrm{C}$. Gas samples $(3 \mathrm{ml})$ were collected in Exetainers (Labco Limited, High Wycombe, UK). Aqueous samples (1 ml) for chemical analyses were filter sterilized through autoclaved nylon filters $(0.2-\mu \mathrm{m}$ pore size; Infochroma, Zug, Switzerland) and stored at $-20{ }^{\circ} \mathrm{C}$ in sterile safe-lock tubes (Eppendorf, Hamburg, Germany).

\section{Methanogenic-enrichment culture}

The enrichment medium contained (in $\mathrm{mgl}^{-1}$ ) mineral salts $\left(\mathrm{KH}_{2} \mathrm{PO}_{4} 10 ; \mathrm{NH}_{4} \mathrm{Cl} 4.6 ; \mathrm{MgCl}_{2} \bullet 6 \mathrm{H}_{2} \mathrm{O}\right.$ 10; $\mathrm{CaCl}_{2} \bullet 2 \mathrm{H}_{2} \mathrm{O}$ 10, (modified from Wüst et al., 2009b)), trace metals $\left(\mathrm{MnSO}_{4} \bullet \mathrm{H}_{2} \mathrm{O} 2.5 ; \mathrm{FeCl}_{2} \bullet 4 \mathrm{H}_{2} \mathrm{O}\right.$ 0.7; $\mathrm{CoCl}_{2} \bullet 2 \mathrm{H}_{2} \mathrm{O}$ 1; $\mathrm{CaCl}_{2} \bullet 2 \mathrm{H}_{2} \mathrm{O} \quad 1 ; \mathrm{ZnCl}_{2} \quad 0.5$; $\mathrm{AlK}\left(\mathrm{SO}_{4}\right)_{4} \bullet 12 \mathrm{H}_{2} \mathrm{O} \quad 0.2 ; \mathrm{H}_{3} \mathrm{BO}_{3} \quad 0.1 ; \mathrm{Na}_{2} \mathrm{MoO}_{4} \bullet 2 \mathrm{H}_{2} \mathrm{O}$ $0.1 ; \quad \mathrm{CuSO}_{4} \bullet 5 \mathrm{H}_{2} \mathrm{O} \quad 0.1 ; \quad \mathrm{Na}_{2} \mathrm{WO}_{4} \bullet 2 \mathrm{H}_{2} \mathrm{O} \quad 0.05$; $\mathrm{NiCl}_{2} \bullet 2 \mathrm{H}_{2} \mathrm{O} 0.2 ; \mathrm{H}_{2} \mathrm{SeO}_{3} 0.5$ (modified Balch et al., 1979)), $10 \mathrm{ml}$ vitamin solution (Balch et al., 1979), $0.5 \mathrm{~g}$ yeast extract, $0.5 \mathrm{~g}$ tryptone, $15 \mathrm{~g} \mathrm{NaHCO}_{3}$, $0.1 \mathrm{mg}$ resazurin, $0.03 \mathrm{~g}$ cysteine and $0.03 \mathrm{~g} \mathrm{NaS}$. The $\mathrm{pH}$ was 7 . Enrichments were incubated at $25^{\circ} \mathrm{C}$ 
with a $\mathrm{CO}_{2}$ head space and supplemented with either $22 \mathrm{mM} \mathrm{H}_{2}$ or $5 \mathrm{~mm}$ acetate for 14 days. Unsupplemented microcosms served as controls. Enrichments were prepared in triplicate.

\section{Analytical methods}

The pressure in the incubation bottles was measured with a pressure transducer (DMG 2120, Ballmoos Elektronik AG, Horgen, Switzerland). The pH of liquid samples was measured with a pH-Meter (WTW pH 330, Wissenschaftliche Werkstätten, Weilheim, Germany) and was used for calculating $\mathrm{CO}_{2}$ production. The fresh weight (FW) of gut content at each sampling point was calculated by subtracting the amount of gut content removed at previous samplings. Gas concentrations of $\mathrm{CO}_{2}, \mathrm{H}_{2}$ and $\mathrm{CH}_{4}$ were determined with a SRI8610C gas chromatograph (SRI Instruments, Torrance, CA, USA). $\mathrm{CH}_{4}$ and $\mathrm{H}_{2}$ were separated with a Molecular Sieve Column $(13 \times, 2 \mathrm{~m} \times 1 / 8$ in; Restek, Bellefonte, PA, USA). $\mathrm{CO}_{2}$ was separated with a HayeSep-D column $(2 \mathrm{~m} \times 1 / 8$ in; SRI instruments). The carrier gas was helium at a flow rate of $40 \mathrm{mlmin}^{-1}$ for $\mathrm{CO}_{2}$ and $20 \mathrm{mlmin}^{-1}$ for $\mathrm{CH}_{4}$ and $\mathrm{H}_{2}$. The oven temperature was $60^{\circ} \mathrm{C}$. The temperature of the detector (thermal conductivity detector) for $\mathrm{CO}_{2}$ was $175^{\circ} \mathrm{C}$. The temperature of the detector (helium ionization detector) for $\mathrm{CH}_{4}$ and $\mathrm{H}_{2}$ was $150^{\circ} \mathrm{C}$. Gas concentrations were calculated as previously described (Küsel and Drake, 1995). Organic compounds in the aqueous phase were analyzed by high performance liquid chromatography as previously described (Wüst et al., 2009a). The ${ }^{13} \mathrm{C}$ content of $\mathrm{CH}_{4}$ and $\mathrm{CO}_{2}$ was determined by gas chromatograph combustion isotoperatio mass spectrometry as previously described (Conrad et al., 2007). The $\mathrm{CH}_{4}$ emitted by living earthworms was measured with a Hewlett-Packard Co. 5980 series II gas chromatograph (Hewlett-Packard, Palo Alto, CA, USA) (Küsel and Drake, 1995).

\section{Extraction of nucleic acids}

Nucleic acids were extracted as previously described (Depkat-Jakob et al., 2012), and the extracts of each replicate were pooled per treatment. DNA was degraded by treatment with $1 \mathrm{U}$ DNAse I per $\mu$ l (Fermentas GmbH, St Leon-Rot, Germany), and RNA was purified by precipitation with 0.7 volume isopropyl alcohol and 0.1 volume of $5 \mathrm{~mm}$ sodium chloride (Merck KGaA, Darmstadt, Germany). The removal of DNA was confirmed by the inability to amplify $16 \mathrm{~S}$ rRNA gene fragments by PCR without reverse transcription (see below).

RNA stable isotope probing (RNA SIP)

RNA SIP was performed per published protocol (Whiteley et al., 2007). A gradient solution (buoyant density of $1.793 \pm 0.002 \mathrm{~g} \mathrm{ml}^{-1}$ ) was prepared by mixing $4.61 \mathrm{ml}$ caesiumtrifluoroacetate solution (buoyant density: $2.0 \pm 0.05 \mathrm{~g} \mathrm{ml}^{-1}$; GE Healthcare,
Buckinghamshire, UK), $0.175 \mathrm{ml}$ formamide and a variable amount of gradient buffer $(100 \mathrm{~mm} \mathrm{KCl}$, $100 \mathrm{~mm}$ Tris, $1 \mathrm{~mm}$ EDTA, $\mathrm{pH}$ 8). The gradient solution was added to 68-506 ng RNA and placed in 4.9-ml OptiSeal Polyallomer Tubes $(13 \times 48 \mathrm{~mm}$; Beckmann, Palo Alto, CA, USA). A centrifugation tube filled with gradient solution and $20 \mu \mathrm{l}$ diethylpyrocarbonate (DEPC) $-\mathrm{H}_{2} \mathrm{O}$ served as blank for determining the densities of fractions after centrifugation. All gradients were set up with the same gradient solution. The separation of $\left[{ }^{12} \mathrm{C}\right]$-RNA and $\left[{ }^{13} \mathrm{C}\right]$-RNA was achieved by isopycnic centrifugation at $130000 \mathrm{~g}$ (37 800 r.p.m.) at $20^{\circ} \mathrm{C}$ for $67 \mathrm{~h}$ in a LE-70 ultracentrifuge (Beckman Coulter, Fullerton, CA, USA). The rotor stopped without braking. Ten fractions $(0.45 \mathrm{ml})$ of each gradient were collected manually (Manefield et al., 2002) using a suction pump (Econo Pump1, Bio-Rad, Hercules, CA, USA). The densities of the fractions were determined by weighting at $25^{\circ} \mathrm{C}$. RNA in each fraction was precipitated according to Lottspeich and Engels (2006). In all, $200 \mu \mathrm{l}$ of RNA was mixed with $130 \mu \mathrm{l}$ of $3 \mathrm{M}$ RNAse-free sodium acetate buffer ( $\mathrm{pH} 5.2$ ), $13.6 \mu \mathrm{l}$ of a sterilized solution of $10 \mathrm{mg}$ glycogen per $\mathrm{ml}$ and $1020 \mu \mathrm{l}$ of ice-cold $96 \%$ ethanol. RNA was precipitated overnight at $-20^{\circ} \mathrm{C}$ and centrifuged for $20 \mathrm{~min}$ at 14000 r.p.m. and $4{ }^{\circ} \mathrm{C}$. The supernatant was removed, and the RNA-pellet was washed with $500 \mu \mathrm{l}$ of ice-cold RNAse-free $70 \%$ ethanol. The purified RNA was eluted in DEPC- $\mathrm{H}_{2} \mathrm{O}$. The concentration of RNA in each fraction was determined with a Quant-iT RiboGreen RNA Kit (Invitrogen, Eugene, OR, USA). RNA was stored at $-80^{\circ} \mathrm{C}$.

\section{Reverse transcription and PCR amplification}

Extracted RNA was transformed into complementary DNA (cDNA) by reverse transcription with SuperScript III reverse transcriptase as previously described (Depkat-Jakob et al., 2012). PCR amplification of bacterial 16S rRNA genes from cDNA was performed with the primers $27 \mathrm{~F}$ and 907RM (5'-AGAGTTTGATCMTGGCTC-3'; 5'-CCGTCAATTC MTTTGAGTTT-3'; Lane, 1991). The PCR conditions were as follows: initial denaturation at $95^{\circ} \mathrm{C}$ for $5 \mathrm{~min}, 5$ cycles at $95^{\circ} \mathrm{C}$ for $60 \mathrm{~s}$, at $40^{\circ} \mathrm{C}$ for $60 \mathrm{~s}$, and at $72{ }^{\circ} \mathrm{C}$ for $90 \mathrm{~s}$, and 35 subsequent cycles at $95^{\circ} \mathrm{C}$ for $60 \mathrm{~s}$, at $50{ }^{\circ} \mathrm{C}$ for $30 \mathrm{~s}$, and at $72^{\circ} \mathrm{C}$ for $90 \mathrm{~s}$. The final elongation was at $72{ }^{\circ} \mathrm{C}$ for $5 \mathrm{~min}$. Final concentrations of PCR reagents were $1 \times 5$ Prime Master Mix (5Prime, Hamburg, Germany), $1 \mathrm{~mm}$ magnesium chloride and $0.6 \mu \mathrm{M}$ of each primer. cDNA of mcrA and mrtA transcripts of the RNA SIP analysis and mcrA and mrtA of the methanogenic $\mathrm{H}_{2}-\mathrm{CO}_{2}$ enrichment culture were amplified as previously described (Depkat-Jakob et al., 2012).

\section{Sequence analyses}

Cloning of PCR products for mcrA, mrtA and $16 \mathrm{~S}$ rRNA cDNA retrieved from pooled fractions 
2 and 3 (representing the 'heavy' [labeled] RNA; buoyant density: $1.803 \pm 0.001-1.794 \pm 0.003 \mathrm{~g} \mathrm{ml}^{-1}$; Supplementary Figure S1) and from pooled fractions 9 and 10 (representing the 'light' [unlabeled] RNA; buoyant density: $1.743 \pm 0.003-1.735 \pm$ $0.004 \mathrm{~g} \mathrm{ml}^{-1}$; Supplementary Figure S1), and also of PCR products obtained from the enrichment culture, was performed as previously described (Schmidt et al., 2014). PCR products of clones with correct inserts were selected for sequencing at Macrogen Europe (Amsterdam, the Netherlands). Sequences were analyzed with MEGA 5.1 (Tamura et al., 2011), ARB (Version 2005; Ludwig et al., 2004) and BLASTn (Altschul et al., 1990). McrA and mrtA clone sequences and reference sequences were translated in silico into amino-acid sequences and aligned with ARB, resulting in a final alignment of 130 aligned amino-acid positions. SINA Webaligner was applied to align 16S rRNA cDNA sequences, which were then merged with the 16S rRNA gene database from SILVA homepage (http://www.arb-silva.de/; last visit: 15/01/13; Pruesse et al., 2007). The resulting alignment contained 880 aligned nucleotide positions. Chimeric 16S rRNA cDNA gene sequences were identified as described (Schmidt et al., 2014). Potential chimeric sequences were blasted (BLASTn) and corrected by removing the shorter part of the sequence at the connection point of the different fragments. Retrieved amino-acid sequences were assigned to different Operational Taxonomic Units (OTUs) with DOTUR (Schloss and Handelsman, 2005). A conservative threshold value of $87.5 \%$ was used for determining family-level OTUs of $16 \mathrm{~S}$ rRNA gene sequences (Yarza et al., 2008). A conservative threshold value of $85.7 \%$ was used for creating species-level OTUs of mcrA and mrtA sequences (Hunger et al., 2011); a maximal identity of $\leqslant 85.7 \%$ is indicated by 'spp.' after the genus name. The classification of $16 \mathrm{~S}$ rRNA gene sequences was accomplished with the RDP classifier (Wang et al., 2007), by DOTUR analysis and via BLASTn. A sequence was assigned to a novel family when the maximum identity to a known sequence in the NCBI database was $<87.5 \%$. The coverage of the gene libraries was calculated according to Schloss et al. (2004), and rarefaction curves were constructed with aRarefact (http://www. uga.edu/ strata/software; last accessed: 8 January 2013) (Hurlbert, 1971; Heck et al., 1975).

\section{Phylogenetic analyses}

Phylogenetic trees of mcrA and mrtA were constructed with ARB by applying the algorithms neighbor-joining (Kimura correction (Saitou and Nei, 1987); 10000 boostraps), maximum-likelihood (Dayhoff PAM modell, Phylip PROML; 100 bootstraps) and maximum-parsimony (Phylip PROTPARS; 500 bootstraps). Phylogenetic trees of mcrA and $m r t A$ were based on a $100 \%$ similarity filter and 130 valid amino acids between positions 327 and 457 of mcrA of Methanocella paludicola SANAE.
Phylogenetic trees of $16 \mathrm{~S}$ rRNA cDNA sequences were constructed using neighbor-joining (Felsenstein correction (Felsenstein, 1985; Saitou and Nei, 1987); 10000 bootstraps), AxML and maximumparsimony methods and applying a $100 \%$ similarity filter of 880 valid nucleotides between positions 26 and 906 of the 16S rRNA gene sequence of Escherichia coli ATCC 11775.

Nucleotide sequence accession numbers

Sequences were submitted to the European Nucleotide Archive (accession numbers: HG964568HG964633 (16S rRNA), HG964544-HG964567 (mcrA and mrtA of RNA SIP), and LK936462-LK936502 (mcrA and mrtA of methanogenic enrichment)).

\section{Results}

The experiments outlined below were designed to first demonstrate that E. eugeniae emitted $\mathrm{CH}_{4}$ in vivo and to subsequently examine the capacity of gut contents from $E$. eugeniae to dissimilate glucose, selected as a model saccharide found in the gut. $\left[{ }^{13} \mathrm{C}\right]$-glucose was utilized as substrate (a) so that glucose-derived carbon could be traced to $\mathrm{CH}_{4}$ and (b) for the RNA SIP-based assessment of taxa involved in the methanogenic food web.

In vivo emission of $\mathrm{CH}_{4}$

E. eugeniae emitted $\mathrm{CH}_{4}$, with the average in vivo emission approximating $40 \mathrm{nmol} \mathrm{CH}_{4}$ per gram $\mathrm{FW}$ in $5 \mathrm{~h}$ (Figure 1).

\section{Dissimilation of glucose}

Approximately $90 \mu \mathrm{mol}$ supplemental glucose per gram FW gut content was consumed within $18 \mathrm{~h}$ in the $\left[{ }^{12} \mathrm{C}\right]$ - and $\left[{ }^{13} \mathrm{C}\right]$-glucose treatments (Figure 2a). Glucose consumption occurred without apparent delay, indicating that microbes in the gut contents were poised to respond rapidly to nutrient input under anoxic conditions. Approximately $1 \mu \mathrm{mol} \mathrm{\textrm {CH } _ { 4 }}$ per gram FW and $4 \mu \mathrm{mol} \mathrm{CO}_{2}$ per gram $\mathrm{FW}$ accumulated during the preincubation period.

Gaseous (Figure 2) and soluble (Figure 3) products were similar for $\left[{ }^{12} \mathrm{C}\right]$ - and $\left[{ }^{13} \mathrm{C}\right]$-glucose treatments. Up to approximately 88 and $74 \mu \mathrm{mol} \mathrm{H}_{2}$ per gram FW accumulated during the $\left[{ }^{12} \mathrm{C}\right]-$ and $\left[{ }^{13} \mathrm{C}\right]$-glucose treatments, respectively, whereas only approximately $5 \mu \mathrm{mol} \mathrm{H}_{2}$ per gram $\mathrm{FW}$ was detected in unsupplemented controls (values are the difference between $t_{0}$ and $t_{24}$ time points) (Figure 2d). $\mathrm{CO}_{2}$ accumulation was rapid and relatively linear after the addition of glucose and yielded approximately 135 and $119 \mu \mathrm{mol} \mathrm{CO} \mathrm{CO}_{2}$ per gram FW during the $\left[{ }^{12} \mathrm{C}\right]-$ and $\left[{ }^{13} \mathrm{C}\right]$-glucose treatments, respectively (values are the difference between $t_{0}$ and $t_{24}$ time points) (Figure 2c). The accumulated $\mathrm{CO}_{2}$ in the $\left[{ }^{13} \mathrm{C}\right]-$ glucose treatment was strongly enriched in ${ }^{13} \mathrm{C}$, 
reaching 70 atom $\%$. Approximately $14 \mu \mathrm{mol} \mathrm{CO} \mathrm{CO}_{2}$ per gram FW accumulated in the unsupplemented controls (Figure 2c) (value is the difference between $t_{0}$ and $t_{24}$ time points).

Approximately $6 \mu \mathrm{mol} \mathrm{CH}_{4}$ per gram $\mathrm{FW}$ accumulated in glucose treatments, whereas approximately half this much $\mathrm{CH}_{4}$ accumulated in unsupplemented controls (Figure 2b) (values are the difference between $t_{0}$ and $t_{24}$ time points). The accumulated $\mathrm{CH}_{4}$ in the $\left[{ }^{13} \mathrm{C}\right]$-glucose treatment was strongly enriched in ${ }^{13} \mathrm{C}$, reaching 50 atom\%. Based on a linear in vivo emission of $\mathrm{CH}_{4}$ (Depkat-Jakob et al., 2012) and an hourly in vivo emission rate of

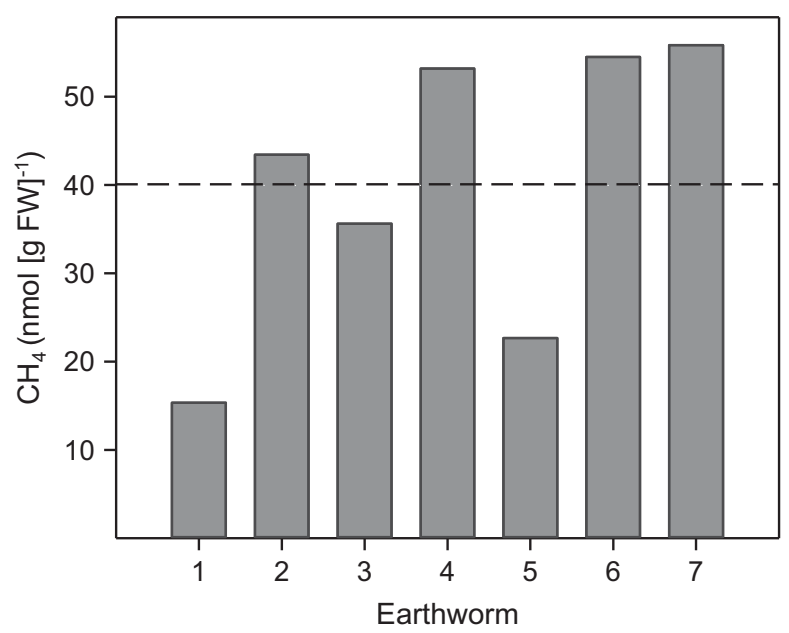

Figure 1 In vivo emission of $\mathrm{CH}_{4}$ by seven individual specimens of $E$. eugeniae. Values represent the amount of $\mathrm{CH}_{4}$ emitted during a 5 -h incubation period under an atmosphere of air. The dashed line indicates the mean value. approximately $8 \mathrm{nmol} \mathrm{CH}_{4}$ per g FW earthworm (calculated from Figure 1), approximately $0.2 \mu \mathrm{mol}$ $\mathrm{CH}_{4}$ per g FW earthworm would be emitted in vivo in $24 \mathrm{~h}$. In contrast, approximately $3 \mu \mathrm{mol} \mathrm{CH}_{4}$ per g FW gut content was produced during the 24-h incubation without supplemental glucose (this value is the difference between the $t_{0}$ and $t_{24}$ time points). In addition, approximately $1 \mu \mathrm{mol} \mathrm{CH}_{4}$ per g FW gut content was produced during the overnight preincubation. Thus, on a FW basis, the gut content produced substantially more $\mathrm{CH}_{4}$ than did living earthworms, a result consistent with the fact that the gut content represents a very small amount of the total FW of the earthworm but is nonetheless the source of the $\mathrm{CH}_{4}$ that is emitted in vivo.

Diverse fermentations were substantially more stimulated by supplemental glucose than was methanogenesis (Figures 2 and 3). Formate, ethanol, lactate and succinate were produced and subject to subsequent consumption in glucose treatments; in contrast, acetate and propionate accumulated as end products in glucose treatments (Figure 3). Trace amounts of butyrate and isobutyrate were detected in controls and glucose treatments. At the end of the $24 \mathrm{~h}$ of incubation, approximately $69 \%$ and $61 \%$ of supplemented carbon and approximately $63 \%$ and $53 \%$ of supplemented electrons were recovered in the detected products of the $\left[{ }^{13} \mathrm{C}\right]-$ and $\left[{ }^{12} \mathrm{C}\right]$-glucose treatments, respectively (Table 1). Unrecovered carbon and electrons may have been due in part to non-detected processes (for example, poor recovery of $\mathrm{CO}_{2}$ because of undetected carbonates, nondetected fermentation products or incomplete recovery of those detected, formation of storage polymers and assimilation of carbon).

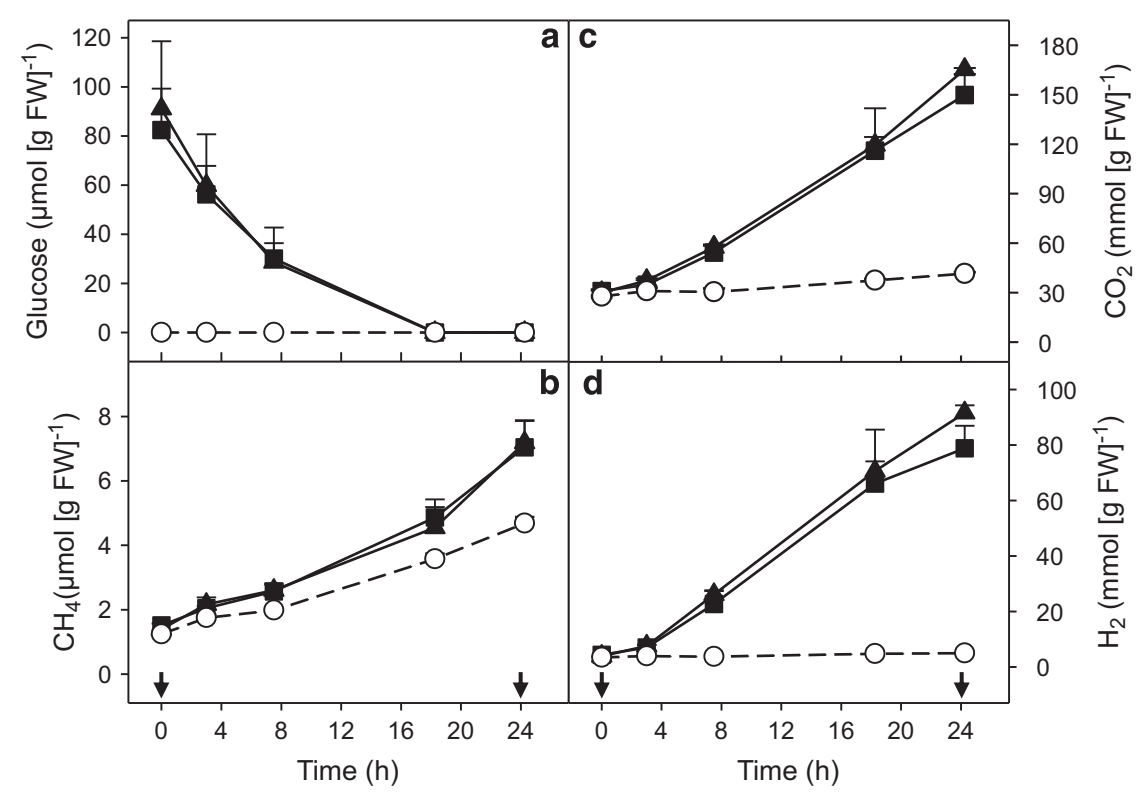

Figure 2 Effect of supplemental glucose (a) on the production of $\mathrm{CH}_{4}(\mathbf{b}), \mathrm{CO}_{2}$ (c) and $\mathrm{H}_{2}$ (d) by the gut contents of E. eugeniae incubated under anoxic conditions. Symbols represent the mean of triplicate incubations, and error bars represent the s.d. Arrows indicate the time point at which the samples were taken for RNA-SIP analysis. Symbols: empty circles, control (no supplemental glucose); filled squares, $\left[{ }^{13} \mathrm{C}\right]$-glucose treatments; filled triangles, $\left[{ }^{12} \mathrm{C}\right]$-glucose treatments. 


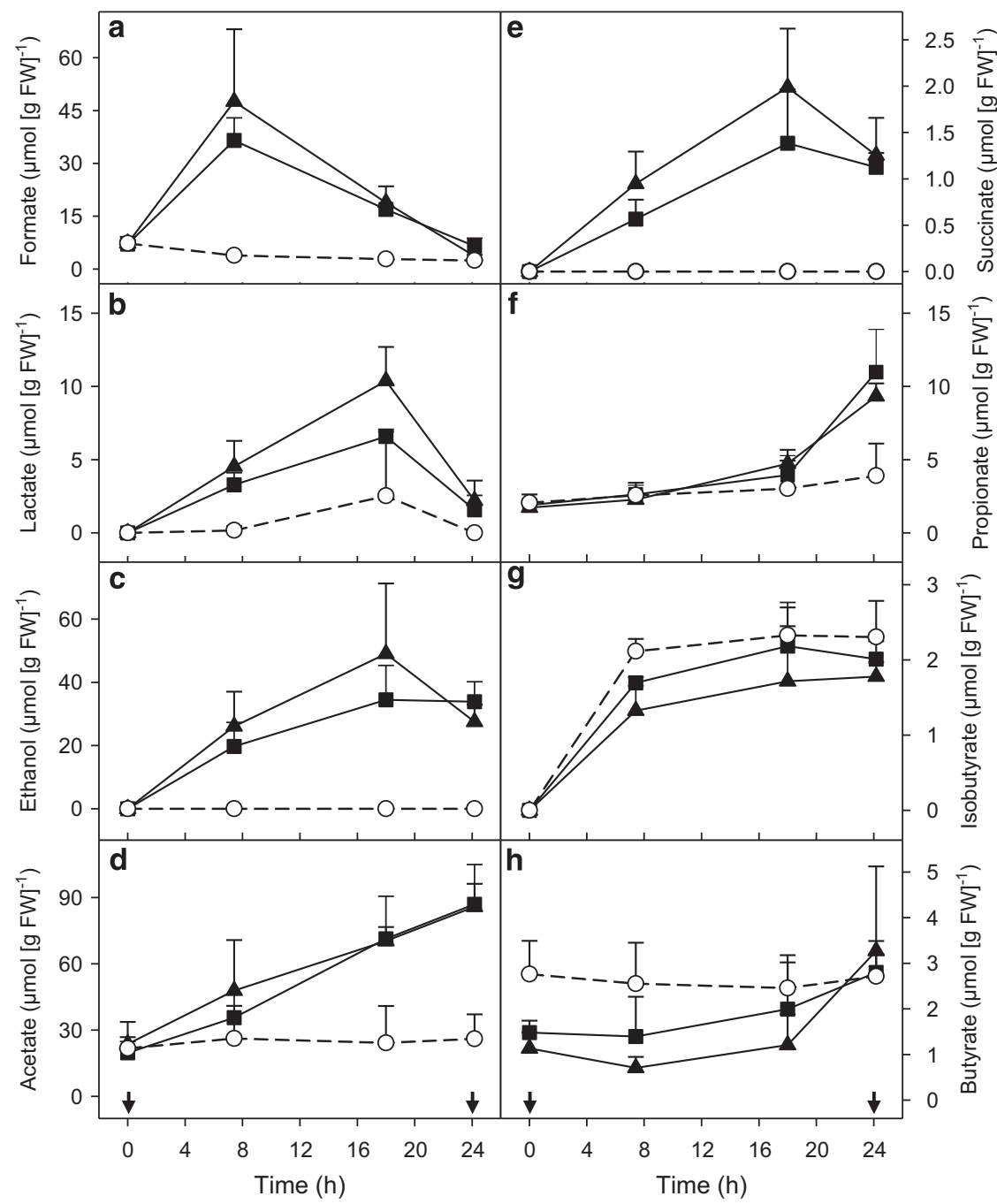

Figure 3 Effect of supplemental glucose on the production of formate (a), lactate (b), ethanol (c), acetate (d), succinate (e), propionate (f), isobutyrate (g) and butyrate (h) by the gut contents of E. eugeniae incubated under anoxic conditions. Symbols represent the mean of triplicate incubations, and error bars indicate the s.d. Arrows indicate the time point at which the samples were taken for RNA-SIP analysis. Symbols: empty circles, control (no supplemental glucose); filled squares, $\left[{ }^{13} \mathrm{C}\right]-$ glucose treatments; filled triangles, $\left[{ }^{12} \mathrm{C}\right]$-glucose treatments.

Detected bacteria

A total of 528 bacterial $16 \mathrm{~S}$ rRNA cDNA sequences were analyzed. The family-level coverage per clone library ranged between $85 \%$ and $94 \%$ (Supplementary Table S1), and rarefaction analyses confirmed that sequencing was sufficient for familylevel coverage (Supplementary Figure S2A). Sequences from all clone libraries were affiliated with 46 different families and sub-orders; four families were defined as novel (Table 2). Families (and sub-orders) were assigned to the phyla Firmicutes $(46.2 \%)$, Proteobacteria (19.5\%, dominated by Gammaproteobacteria (11.4\%)), Actinobacteria (16.5\%), Fusobacteria (5.5\%), Planctomycetes $(5.5 \%)$, Tenericutes $(4.5 \%)$, Spirochaetes $(0.8 \%)$, Verrucomicrobia (0.8\%), Bacterioidetes $(0.6 \%)$ and Chloroflexi (0.2\%) (Figure 4a and Table 2). Sequences obtained from cDNA at the start of incubation were related to 28 different families and sub-orders (Table 2). Those sequences were mostly related to the phyla Actinobacteria $(21.7 \%)$, Fusobacteria (15.0\%) and Firmicutes (28.3\%), of which $39.2 \%$ were related to the family Peptostreptococcaceae (Figure 4a).

The bacterial 16S rRNA cDNA sequences obtained from the glucose treatments at the end of the 24-h incubation were affiliated with 41 different families and sub-orders (Table 2). Those sequences were mostly related to the phyla Firmicutes $(55.2 \%)$, Proteobacteria (20.4\%, dominated by Gammaproteobacteria (12.9\%)) and Actinobacteria (13.8\%) (Figure 4a). Lachnospiraceae I (18.1\%), Peptostreptococcaceae (14.1\%) and Aeromonadeaceae $(9.8 \%)$ were the most abundant families.

Bacterial community composition

The shift of the buoyant densities of extracted RNA from $\left[{ }^{13} \mathrm{C}\right]$-glucose treatments toward fractions with higher densities (Supplementary Figure S1) 
Table 1 Recoveries of carbon (C-mol balance) and electrons (E-mol balance) in the detected products at the end of the 24-h incubation

\begin{tabular}{|c|c|c|c|c|c|c|}
\hline \multirow[t]{2}{*}{ Products } & \multicolumn{2}{|c|}{$\begin{array}{l}\text { Concentration of the detected } \\
\text { products }\left(\mu \mathrm{mol}(\mathrm{gFW})^{-1}\right)\end{array}$} & \multicolumn{2}{|c|}{ C-mol balance (\%) } & \multicolumn{2}{|c|}{ E-mol balance (\%) } \\
\hline & {$\left[{ }^{12} C\right]-G l C$} & {$\left[{ }^{13} C\right]-G l_{C}$} & {$\left[{ }^{12} C\right]-G l C$} & {$\left[{ }^{13} \mathrm{C}\right]$-GlC } & {$\left[{ }^{12} C\right]-G l C$} & {$\left[{ }^{13} C\right]-G l C$} \\
\hline Carbon dioxide & 121.4 & 105.1 & 22.2 & 21.3 & NA & NA \\
\hline Methane & 2.3 & 2.1 & 0.4 & 0.4 & 0.9 & 0.8 \\
\hline Hydrogen & 86.1 & 72.9 & NA & NA & 7.9 & 7.4 \\
\hline Formate & 1.3 & 4.3 & 0.2 & 0.9 & 0.1 & 0.4 \\
\hline Lactate & 2.2 & 1.6 & 1.2 & 1.0 & 1.2 & 1.0 \\
\hline Ethanol & 27.5 & 33.9 & 10.1 & 13.7 & 15.1 & 20.6 \\
\hline Acetate & 57.8 & 62.9 & 21.2 & 25.5 & 21.2 & 25.5 \\
\hline Succinate & 1.3 & 1.1 & 0.9 & 0.9 & 0.8 & 0.8 \\
\hline Propionate & 5.8 & 7.2 & 3.2 & 4.4 & 3.7 & 5.1 \\
\hline Butyrate & 2.2 & 1.4 & 1.6 & 1.1 & 2.0 & 1.4 \\
\hline Total & 307.9 & 292.1 & 61.0 & 69.1 & 52.8 & 62.9 \\
\hline
\end{tabular}

Abbreviations: FW, fresh weight; NA, not applicable. The concentrations of the detected products represent means of triplicates and are based on the differences between the $t_{0}$ and $t_{24}$ time points, corrected by the concentration of the detected products of the unsupplemented controls. Balances are based on the amount of carbon or electrons recovered in the products versus the amount of carbon or electrons available in the glucose that was consumed.

reinforces the likelihood that some of the glucosederived carbon was assimilated by microorganisms in the E. eugeniae gut content. The bacterial community structure of 'heavy' fractions of the $\left[{ }^{13} \mathrm{C}\right]$-treatment was distinct from that of the 'light' fractions of the $\left[{ }^{13} \mathrm{C}\right]$-treatment and 'heavy' fractions of the $\left[{ }^{12} \mathrm{C}\right]$-glucose treatment (Figure 4a). 16S rRNA cDNA sequences obtained from 'heavy' fractions of the $\left[{ }^{13} \mathrm{C}\right]$-glucose treatment at the end of the 24 -h incubation were affiliated with 12 different families and sub-orders, most of which were related to Aeromonadaceae $(27.8 \%)$ and Lachnospiraceae I $(27.8 \%)$ (Table 2). Sequences assigned to those families were closely related to Aeromonas hydrophila strain ANSE1 (GU296671, 99\% similarity, Supplementary Table S3) and Clostridium propionicum strain JCM 1430 (AB649276, 97-99\% similarity, Supplementary Table S3). Veillonellaceae- and Ruminococcaceae-affiliated sequences were also mainly abundant in the 'heavy' fractions of the $\left[{ }^{13} \mathrm{C}\right]$-glucose treatment (Table 2). Sequences assigned to Veillonellaceae and Ruminococcaceae were closely related to Succinispira mobilis strain 19gly1 (NR_028868, 99\% similarity) and Clostridium viride strain DSM 6836 (NR_026204, 99\% similarity, Supplementary Table S3), respectively. Approximately 19\% of the sequences retrieved from 'heavy' fractions of the $\left[{ }^{13} \mathrm{C}\right]$-glucose treatment were affiliated to Peptostreptococcaceae (Table 2), with the closest known relatives (98-99\% similarity, Supplementary Table S3) being Clostridium mayombei (FR733682) and Clostridium glycolicum strain CIN5 (AY007244).

\section{Detected methanogens}

A total of 497 mcrA and mrtA sequences were assigned to 14 species-level OTUs. The coverage for each clone library was $>97 \%$ (Supplementary Table S2), and rarefaction analyses confirmed that sequencing was sufficient for species-level coverage (Supplementary Figures S2B and C). Sequences retrieved at the start of incubation were affiliated with Methanosarcinaceae (37.2\%), Methanocellaceae $(25.6 \%)$, Methanosaetaceae $(26.1 \%)$ and Methanobacteriaceae (11.1\%) (Figure 4b). The active mcrA community structure changed after $24 \mathrm{~h}$ of incubation; sequences affiliated with Methanoregulaceae were detected, and the relative abundance of Methanosaetaceae and Methanocellaceae was decreased. McrA and mrtA sequences of the 'heavy' fraction of $\left[{ }^{13} \mathrm{C}\right]$-glucose treatments were assigned to the species-level OTUs 10, 11 and 13. Those OTUs were affiliated with Methanoregula spp. and Methanobacterium formicicum (Figure 5). Sequences related to those species were not detected or were not abundant in 'light' fractions of $\left[{ }^{13} \mathrm{C}\right]$-glucose treatments and 'heavy' fractions of $\left[{ }^{12} \mathrm{C}\right]$-glucose treatments.

\section{Methanogenic-enrichment culture}

The results above suggested that $\mathrm{H}_{2}$ rather than acetate was an important driver of methanogenesis. To evaluate this possibility in more detail, enrichment cultures prepared from the gut content of $E$. eugeniae were supplemented with $\mathrm{H}_{2}-\mathrm{CO}_{2}$ or acetate and incubated for 14 days. Methanogenesis was only stimulated by $\mathrm{H}_{2}-\mathrm{CO}_{2}\left(0.8 \mathrm{~mm} \mathrm{CH}_{4}\right.$ compared with $0.1 \mathrm{~mm} \mathrm{CH}_{4}$ in controls lacking $\mathrm{H}_{2}$ ). Two species-level mrtA and four species-level mcrA phylotypes affiliated with Methanobacteriaceae were detected in the $\mathrm{H}_{2}-\mathrm{CO}_{2}$ enrichments. The relative abundance of phylotypes and affiliated species were: 39\% Methanobacterium ivanovii (mrtA), 34\% M. ivanovii (mcrA), 15\% Methanobacterium sp. (mcrA), 5\% Methanobacterium formicicum (mrtA), 5\% M. formicicum (mcrA), and $2 \%$ Methanobacterium kanagiense (mcrA). It is noteworthy that acetate production was more 
Table 2 Phylogenetic distribution of bacterial $16 \mathrm{~S}$ rRNA cDNA sequences retrieved from RNA of $\left[{ }^{13} \mathrm{C}\right]-$ and $\left[{ }^{12} \mathrm{C}\right]$-glucose treatments

\begin{tabular}{|c|c|c|c|c|c|c|c|}
\hline \multicolumn{2}{|c|}{ Phylogenetic affiliation ${ }^{\mathrm{a}}$} & \multicolumn{6}{|c|}{ Relative abundance of sequences (\%) } \\
\hline \multirow[t]{2}{*}{ Phylum and classes } & \multirow[t]{2}{*}{ Order, sub-order (*) and family } & \multicolumn{4}{|c|}{$\left[{ }^{13} C\right]$-glucose } & \multicolumn{2}{|c|}{$\left[{ }^{12} C\right]$-glucose } \\
\hline & & $\mathrm{t}_{o}, L$ & $\mathrm{t}_{o}, H$ & $\mathrm{t}_{24}, L$ & $\mathrm{t}_{24}, H$ & $\mathrm{t}_{24}, L$ & $\mathrm{t}_{24}, H$ \\
\hline \multirow[t]{8}{*}{ Actinobacteria (16.5) } & Acidimicrobiales (2.2) & & & & & & \\
\hline & Acidimicrobiaceae & - & 3.3 & 1.2 & - & 1.1 & - \\
\hline & $\begin{array}{l}\text { Unclassified Acidimicrobineae } \\
\text { Actinomycetales (13.3) }\end{array}$ & 3.4 & 1.1 & 1.2 & - & 2.2 & - \\
\hline & $\begin{array}{l}\text { Corynebacterineae* } \\
\text { (Mycobacteriaceae/Dietziaceae/ } \\
\text { Nocardiaceae) }\end{array}$ & 1.1 & 8.7 & 1.2 & 1.1 & 3.3 & 8.1 \\
\hline & $\begin{array}{l}\text { Micrococcineae* } \\
\text { (Microbacteriaceae/Micrococcaceae) }\end{array}$ & 3.4 & 7.6 & 3.7 & - & 4.4 & 3.5 \\
\hline & $\begin{array}{l}\text { Propionibacterineae } \\
\text { (Propionibacteriaceae/Nocardioidaceae) } \\
\text { Coriobacteriales }(0.2)\end{array}$ & 8.0 & 2.2 & 3.7 & 3.3 & 8.8 & 7.0 \\
\hline & $\begin{array}{l}\text { Coriobacteriaceae } \\
\text { Rubrobacterales }(0.8)\end{array}$ & - & 1.1 & - & - & - & - \\
\hline & Rubrobacteraceae & 1.1 & 2.2 & - & - & 1.1 & - \\
\hline \multirow[t]{3}{*}{ Bacterioidetes (0.6) } & Bacteroidales (0.4) & & & & & & \\
\hline & $\begin{array}{l}\text { Porphyromonadaceae } \\
\text { Cytophagales }(0.2)\end{array}$ & 1.1 & - & - & 1.1 & - & - \\
\hline & Incertae sedis & - & - & - & - & 1.1 & - \\
\hline \multirow[t]{2}{*}{ Chloroflexi (0.2) } & Anaerolineales (0.2) & & & & & & \\
\hline & Anaerolineaceae & - & 1.1 & - & - & - & - \\
\hline \multirow[t]{14}{*}{ Firmicutes (46.2) } & Bacillales (2.1) & & & & & & \\
\hline & Bacillaceae & 1.1 & 1.1 & 4.9 & - & 1.1 & 3.5 \\
\hline & $\begin{array}{l}\text { Planococcaceae } \\
\text { Clostridiales }(42.0)\end{array}$ & 1.1 & - & - & - & - & - \\
\hline & Clostridiaceae 1 & 5.7 & 5.4 & 3.7 & 1.1 & 6.6 & 8.1 \\
\hline & Lachnospiraceae I(C. propionicum) & - & - & 3.7 & 27.8 & 16.5 & 23.3 \\
\hline & Lachnospiraceae II & 4.6 & 4.4 & 8.6 & 3.3 & 4.4 & 2.3 \\
\hline & Lachnospiraceae III (C. lentocellum) & 2.3 & 1.1 & 5.0 & 1.1 & 2.2 & 1.2 \\
\hline & Peptostreptococcaceae & 10.2 & 12.0 & 12.4 & 18.9 & 14.3 & 10.5 \\
\hline & Peptococcaceae & - & 1.1 & - & - & - & - \\
\hline & Ruminococcaceae & 1.1 & - & 4.9 & 8.9 & 3.3 & 5.8 \\
\hline & $\begin{array}{l}\text { Veillonellaceae } \\
\text { Erysipelotrichales (1.1) }\end{array}$ & - & - & - & 4.4 & 3.3 & - \\
\hline & $\begin{array}{l}\text { Erysipelotrichaceae } \\
\text { Lactobacillales }(0.8)\end{array}$ & 2.3 & 1.1 & 2.5 & - & - & 1.2 \\
\hline & Aerococcaceae & 2.3 & - & 1.2 & - & - & - \\
\hline & Carnobacteriaceae & - & - & 1.2 & - & - & - \\
\hline \multirow[t]{2}{*}{ Fusobacteria (5.5) } & Fusobacteriales (5.5) & & & & & & \\
\hline & Fusobacteriaceae & 20.5 & 9.8 & - & - & 1.1 & 1.2 \\
\hline \multirow[t]{7}{*}{ Planctomycetes (5.5) } & Planctomycetales (5.5) & & & & & & \\
\hline & Planctomycetaceae I (Gemmata) & 2.3 & 8.7 & 1.2 & - & 1.1 & - \\
\hline & $\begin{array}{l}\text { Planctomycetaceae II } \\
\text { (Rhodospirellula) }\end{array}$ & - & 1.1 & - & - & - & 2.3 \\
\hline & Planctomycetaceae III (Pirellula) & 1.1 & 1.1 & 2.5 & - & - & - \\
\hline & $\begin{array}{l}\text { Planctomycetaceae IV } \\
\text { (Isospaera/Sangulispaera) }\end{array}$ & - & 1.1 & 2.5 & - & - & 1.2 \\
\hline & Planctomycetaceae $V$ & 1.1 & 1.1 & 1.2 & - & - & 1.2 \\
\hline & Novel family ${ }^{\mathrm{b}}$ & 1.1 & - & - & - & 1.1 & - \\
\hline \multicolumn{8}{|l|}{ Proteobacteria (19.5) } \\
\hline \multirow[t]{6}{*}{ Alphaproteobacteria (3.2) } & Rhizobiales (1.7) & & & & & & \\
\hline & Hyphomicrobiaceae & - & 3.3 & 5.0 & - & - & - \\
\hline & $\begin{array}{l}\text { Phyllobacteriaceae } \\
\text { Rhodobacterales (0.2) }\end{array}$ & - & - & 2.5 & - & - & - \\
\hline & $\begin{array}{l}\text { Rhodobacteraceae } \\
\text { Rhodospirillales (1.4) }\end{array}$ & - & - & 1.2 & - & - & - \\
\hline & Acetobacteraceae & - & 1.1 & 1.2 & - & 1.1 & 1.2 \\
\hline & Rhodospirillaceae & - & 1.1 & 2.5 & - & - & - \\
\hline \multirow[t]{3}{*}{ Betaproteobacteria (0.8) } & Burkholderiales (0.6) & & & & & & \\
\hline & $\begin{array}{l}\text { Oxalobacteraceae } \\
\text { Neisseriales }(0.2)\end{array}$ & - & 3.3 & - & - & - & - \\
\hline & Neisseriaceae & - & - & 1.2 & - & - & - \\
\hline
\end{tabular}


Table 2 (Continued)

\begin{tabular}{|c|c|c|c|c|c|c|c|}
\hline \multicolumn{2}{|c|}{ Phylogenetic affiliation $^{\mathrm{a}}$} & \multicolumn{6}{|c|}{ Relative abundance of sequences (\%) } \\
\hline \multirow[t]{2}{*}{ Phylum and classes } & \multirow[t]{2}{*}{ Order, sub-order (*) and family } & \multicolumn{4}{|c|}{$\left[{ }^{13} C\right]$-glucose } & \multicolumn{2}{|c|}{$\left[{ }^{12} C\right]$-glucose } \\
\hline & & $\mathrm{t}_{0}, L$ & $\mathrm{t}_{o}, H$ & $\mathrm{t}_{24}, L$ & $\mathrm{t}_{24}, H$ & $\mathrm{t}_{24}, L$ & $\mathrm{t}_{24}, H$ \\
\hline \multirow[t]{4}{*}{ Deltaproteobacteria (4.2) } & Myxococcales (4.2) & & & & & & \\
\hline & Novel family & - & - & 1.2 & - & - & - \\
\hline & Novel family ${ }^{\mathrm{b}}$ & - & - & - & - & - & 1.2 \\
\hline & Polyangiaceae & 8.0 & 2.2 & 6.2 & - & 4.4 & 2.3 \\
\hline \multirow[t]{4}{*}{ Gammaproteobacteria (11.4) } & Aeromonadales (9.3) & & & & & & \\
\hline & $\begin{array}{l}\text { Aeromonadaceae } \\
\text { Enterobacteriales (1.3) }\end{array}$ & 8.0 & 8.7 & - & 27.8 & 7.7 & 2.3 \\
\hline & $\begin{array}{l}\text { Enterobacteriaceae } \\
\text { Methylococcales (0.8) }\end{array}$ & - & - & - & 1.1 & 3.3 & 3.5 \\
\hline & Methylococcaceae & - & - & 2.5 & - & 2.2 & - \\
\hline \multirow[t]{2}{*}{ Spirochaetes (0.8) } & Spirochaetales (0.8) & & & & & & \\
\hline & Leptospiraceae & - & - & - & - & 3.3 & 1.2 \\
\hline \multirow{2}{*}{ Tenericutes (4.5) } & Mycoplasmatales (4.5) & & & & & & \\
\hline & Mycoplasmataceae & 8.0 & 4.4 & 9.9 & - & 1.1 & 4.7 \\
\hline Verrucomicrobia (0.8) & Novel familyb(0.8) & 1.1 & - & - & - & - & 3.5 \\
\hline
\end{tabular}

Abbreviations: H, 'heavy' fraction; L, 'light' fractions; $t_{0}$, sampling point at the start of incubation; $t_{24}$ sampling point after $24 \mathrm{~h}$ of incubation. ${ }^{a}$ Sequences were assigned to bacterial families by using the RDP Classifier, DOTUR analysis and BLASTn search. The number of sequences retrieved from cDNA of 'heavy' and 'light' fractions ranged from 81 to 92 (Supplementary Table S1). The percentage of relative abundances for phyla and orders are shown in parentheses.

${ }^{\mathrm{b}}$ Considered as a novel family based on gene sequence similarities $<87.5 \%$.

significantly stimulated by $\mathrm{H}_{2}-\mathrm{CO}_{2}$ than was methanogenesis (13 mM acetate compared with $6 \mathrm{~mm}$ acetate in controls lacking $\mathrm{H}_{2}$ ), suggesting that $\mathrm{H}_{2}$ enriched not only methanogens from the gut contents of $E$. eugeniae but acetogens as well.

\section{Discussion}

The diverse anaerobic activities that occur in the alimentary canal of earthworms appear to be dominated by ingested microbes that become activated by the unique in situ conditions of the alimentary canal (Karsten and Drake, 1995; Matthies et al., 1999; Furlong et al., 2002; Horn et al., 2003; Drake and Horn, 2007; Knapp et al., 2009; Wüst et al., 2009a; Depkat-Jakob et al., 2012). This generalization for the earthworm gut is in contrast to other invertebrates whose guts are heavily colonized by novel endemic microbes (for example, termites; Brune, 2006; Dietrich et al., 2014). The methanogenic food webs of classic methane-emitting ecosystems such as ruminants and wetlands are primarily linked to the initial hydrolysis of autotrophically produced polymers (for example, the hydrolysis of plant-synthesized lignocelluloses; Morrison et al., 2009; Bridgham et al., 2013). In contrast, the methanogenic food web of E. eugeniae is likely linked to the hydrolysis of heterotrophically produced polymers, that is, the hydrolysis of earthworm-derived polysacchariderich mucus (Wüst et al., 2009a). Indeed, $100 \mathrm{~mm}$ monosaccharide equivalents, including $>10 \mathrm{~mm}$ glucose can occur in the aqueous phase of gut contents (Horn et al., 2003; Wüst et al., 2009a).
Glucose was therefore selected as a model saccharide to experimentally evaluate potential trophic interactions of prokaryotes that yield $\mathrm{CH}_{4}$ in the digestive system of $E$. eugeniae. The rapid and nearly linear production of $\mathrm{H}_{2}$ and $\mathrm{CO}_{2}$ by the gut contents of $E$. eugeniae in response to glucose (Figure 2) corroborate previous studies that demonstrated the capacity of microbes in the alimentary canal of various earthworms to augment anaerobic processes (Karsten and Drake, 1995; Matthies et al., 1999; Wüst et al., 2009a, 2011).

\section{Fermentations and fermenters in E. eugeniae gut contents}

Concomitant as well as successive fermentations were stimulated by supplemental glucose (Figure 3). The production of formate, acetate, succinate, lactate, ethanol, $\mathrm{CO}_{2}$ and $\mathrm{H}_{2}$ is indicative of mixed acid fermentation by facultative aerobes (Gottschalk, 1986). Most sequences retrieved from 'heavy' fractions of $\left[{ }^{13} \mathrm{C}\right]$-glucose treatments were affiliated with Aeromonadaceae, members of which are facultative aerobes (Martin-Carnahan and Joseph, 2005b). A. hydrophila was the closest cultured species to retrieved Aeromonadaceae-related sequences and is a facultative aerobe that can ferment sugars (including glucose) to ethanol, formate, acetate, succinate, $\mathrm{CO}_{2}$ and $\mathrm{H}_{2}$ (Martin-Carnahan and Joseph, 2005a). Certain sequences of 'heavy fractions' from $\left[{ }^{13} \mathrm{C}\right]$-glucose treatments were closely affiliated with C. viride (Ruminococcaceae), an obligate anaerobe that can ferment glucose to acetate, formate, succinate, lactate and ethanol (Ezaki, 1984; Buckel et al., 1994). C. viride is 
a

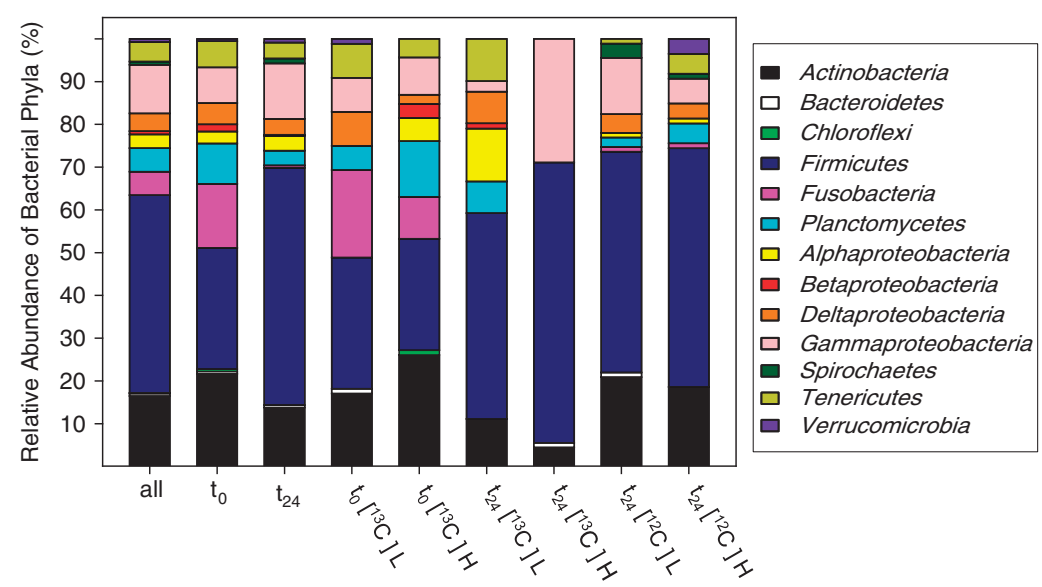

b

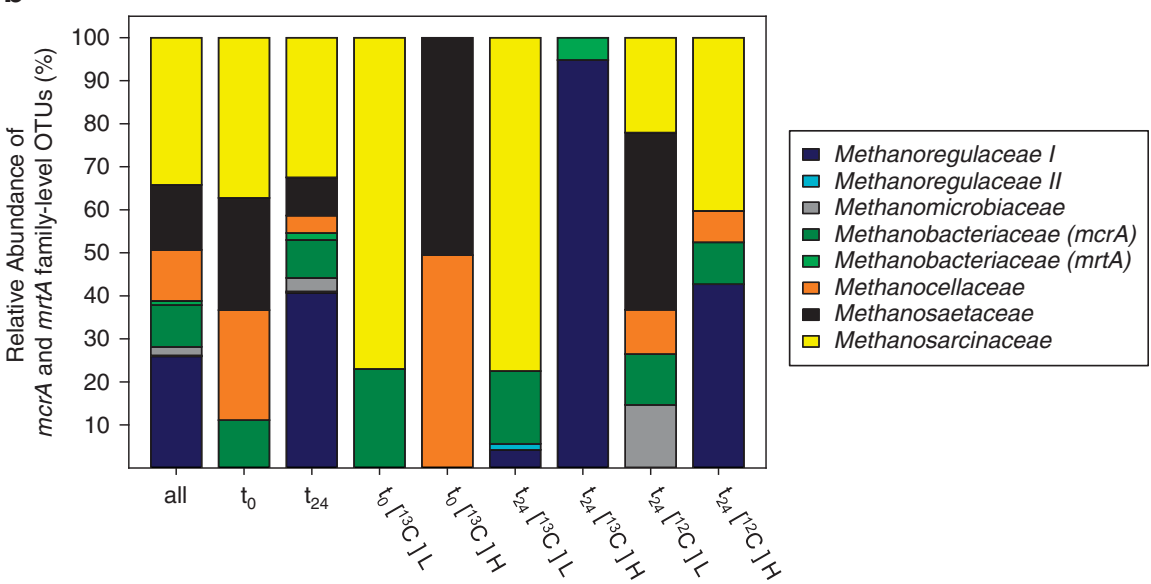

Figure 4 Phylogenetic distribution of bacterial $16 \mathrm{~S}$ rRNA cDNA (a) and mcrA and mrtA (b) sequences of $\left[{ }^{13} \mathrm{C}\right]-$ and $\left[{ }^{12} \mathrm{C}\right]$-glucose treatments. Sequences were assigned to bacterial phyla with the RDP Classifier. Assignment of sequences to methanogenic families was based on $\leqslant 75.4 \%$ gene sequence similarities (Hunger et al., 2011). As indicated in the lower axes, sequence analyses were performed for the total number of sequences (lane designated all), for all sequences at the start $\left(t_{0}\right)$ or at $24 \mathrm{~h}\left(t_{24}\right)$ of incubation and for each fraction per time point and treatment. $\mathrm{H}$, 'heavy' fractions; $\mathrm{L}$, 'light' fraction; $t_{0}$, sampling point at the start of incubation; $t_{24}$, sampling point at $24 \mathrm{~h}$ of incubation; 13 and $12,\left[{ }^{13} \mathrm{C}\right]$ - and $\left[{ }^{12} \mathrm{C}\right]$-glucose treatments, respectively.

likewise able to ferment amino acids (Buckel et al., 1994), suggesting that bacteria related to $C$. viride might have additionally used endogenous amino acids in the earthworm gut contents (Drake and Horn, 2007). The formation of butyrate, isobutyrate and propionate (Figure 3 ) is indicative of the fermentation of amino acids (Nanninga and Gottschal, 1985; Gottschalk, 1986), and the high relative abundance of Peptostreptococcaceaeaffiliated sequences suggests that members of this amino-acid-fermenting taxon (for example, Clostridium lituseburense) may have utilized amino acids (Hippe et al., 1992; Ezaki, 2009).

The production of propionate subsequent to the consumption of lactate and succinate (Figure 3 ) is indicative of Propionibacteria (Stackebrandt et al., 2006). However, propionate production could have also been linked to members of the detected family Lachnospiraceae $I$ that form propionate when utilizing lactate (for example, $C$. propionicum) (Leaver et al., 1955). Members of Veillonellaceae can also produce propionate as well as various volatile fatty acids, $\mathrm{CO}_{2}$ and $\mathrm{H}_{2}$ (Morrison, 1984). Certain sequences were closely related to the Veillonellaceae-affiliated species $S$. mobilis, a strict anaerobe that can ferment organic and amino acids (but not carbohydrates such as glucose) and produce formate, acetate, propionate, $\mathrm{CO}_{2}$ and $\mathrm{H}_{2}$ (Janssen, 1984), compounds detected in the incubations (Figures 2 and 3).

\section{Trophic links of methanogens in the gut contents of E. eugeniae}

$\mathrm{CH}_{4}$ production was not as significantly stimulated by supplemental glucose as was fermentation (Figures 2 and 3). However, ${ }^{13} \mathrm{C}$-labeling of $\mathrm{CH}_{4}$ verified that supplemental $\left[{ }^{13} \mathrm{C}\right]$-glucose-derived carbon was dissimilated to $\mathrm{CH}_{4}$, reinforcing the likelihood that glucose-derived carbon was also assimilated by methanogens. High amounts of the methanogenic substrates $\mathrm{H}_{2}$ and acetate (Zinder, 1993) accumulated in glucose treatments (Figures 2 and 3). These combined findings indicate that methanogens in the 


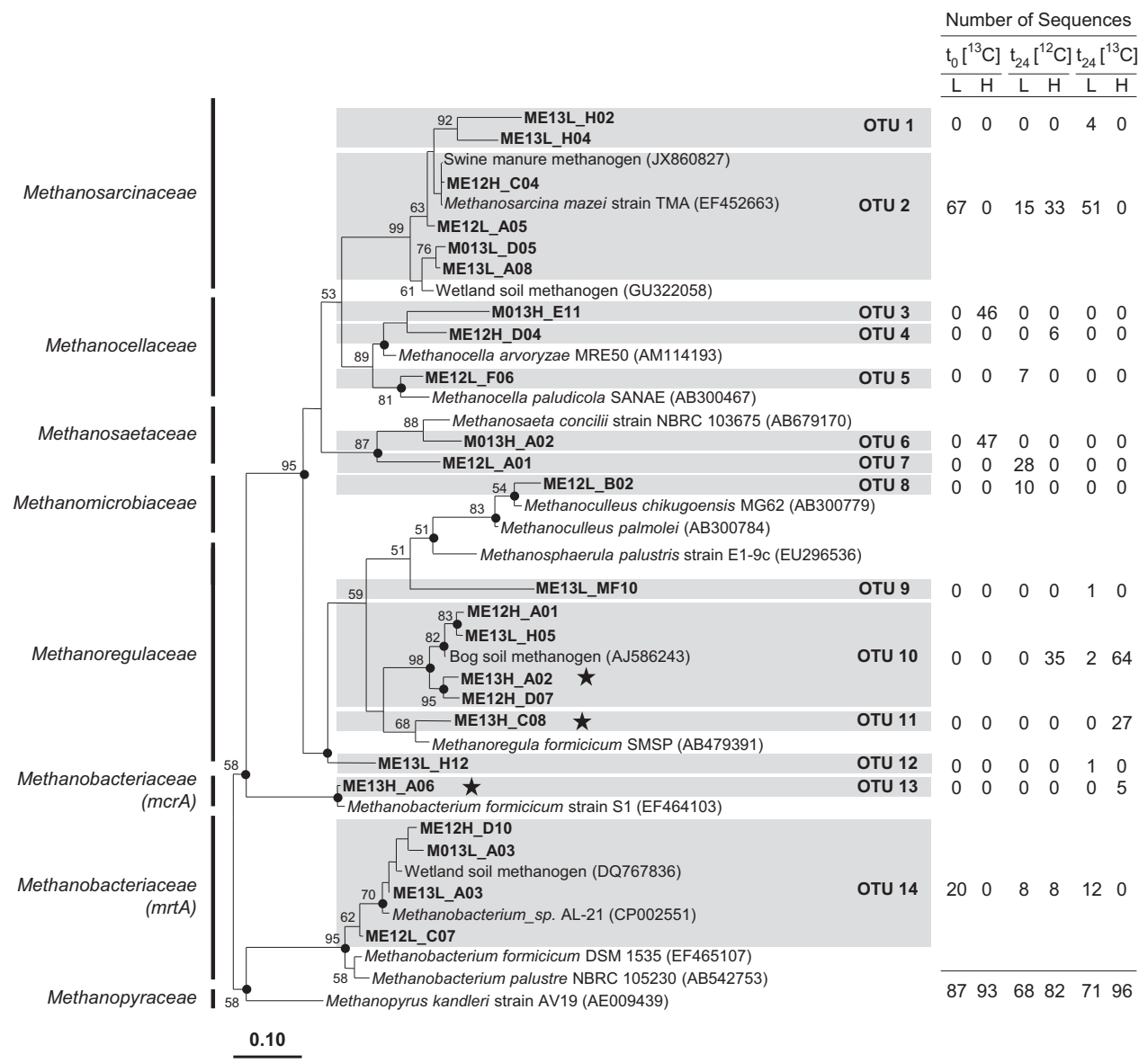

Figure 5 Phylogenetic neighbor-joining tree of representative $\operatorname{mcr} A$ and $\operatorname{mrt} A$ amino-acid sequences of $\left[{ }^{13} \mathrm{C}\right]-$ and $\left[{ }^{12} \mathrm{C}\right]$-glucose treatments. Numbers next to the branches represent the percentages of replicate trees $(>50 \%)$ in which the associated taxa clustered together in the bootstrap test (10000 bootstraps). Dots at nodes indicate the confirmation of the tree topology by maximum-parsimony and maximum-likelihood calculations with the same data set. Bar represents a 0.1 estimated change per amino acid. Accession numbers of reference sequences are in parentheses. Stars identify labeled mcrA and mrtA phylotypes. The table outlines the origin of sequences per species-level OTU (based on $85.7 \%$ gene sequence similarity; Hunger et al., 2011). Abbreviations in sequence identifier code: H, 'heavy' fractions; L, 'light' fractions; M0, methanogen sequence from sampling point $t_{0}$ (that is, at the start of incubation); ME, methanogen sequence from sampling point $t_{24}$ (that is, at $24 \mathrm{~h}$ of incubation); 13 and 12 , $\left[{ }^{13} \mathrm{C}\right]$ - and $\left[{ }^{12} \mathrm{C}\right]$-glucose treatments, respectively.

alimentary canal of E. eugeniae are closer to substrate saturation than are fermentative taxa.

Methanogens of the families Methanosarcinaceae, Methanobacteriaceae and Methanomicrobiaceae were previously detected in the $E$. eugeniae gut contents (Depkat-Jakob et al., 2012), and the detection of mcrA sequences related to these taxa (Figure 4b) suggest that these taxa are linked to methanogenesis in the alimentary canal. Members of Methanosarcinaceae are acetoclastic, that is, can convert acetate to $\mathrm{CO}_{2}$ and $\mathrm{CH}_{4}$ (Boone et al., 1993; Hedderich and Whitman, 2006). However, mcrA sequences related to the genus Methanosarcina were not detected in 'heavy' fractions of $\left[{ }^{13} \mathrm{C}\right]$-glucose treatments in which acetate accumulated (Figure 3). Thus acetate derived from supplemental glucose did not appear to be a dominant substrate for methanogenesis.

Analysis of mcrA sequences from 'heavy' fractions of $\left[{ }^{13} \mathrm{C}\right]$-glucose treatments indicated that methanogens closely related to $M$. formicicum and Methanoregula species were likely involved in the consumption of glucose-derived fermentation products. $M$. formicicum and species of Methanoregula utilize $\mathrm{H}_{2}-\mathrm{CO}_{2}$ and formate (Schauer and Ferry, 1980; Bräuer et al., 2011; Yashiro et al., 2011). However, which source of reductant $\left(\mathrm{H}_{2}\right.$ or formate) was used for methanogenesis remains unclear. Four molecules of $\mathrm{H}_{2}$ or four molecules of formate are needed to produce one molecule of $\mathrm{CH}_{4}$ (Hedderich and Whitman, 2006). Approximately $80 \mu \mathrm{mol} \mathrm{H}_{2}$ per gram $\mathrm{FW}$ accumulated, and approximately $34 \mu \mathrm{mol}$ formate per gram FW transiently accumulated and were subsequently consumed in the $\left[{ }^{13} \mathrm{C}\right]$-glucose treatments (Figures 2 and 3 ), values that could theoretically yield approximately $20 \mu \mathrm{mol} \mathrm{CH}_{4}$ per gram FW and $8 \mu \mathrm{mol} \mathrm{CH}_{4}$ per gram FW, respectively. That only an additional $2 \mu \mathrm{mol} \mathrm{CH}_{4}$ per gram $\mathrm{FW}$ accumulated in glucose treatments compared with the amount of $\mathrm{CH}_{4}$ that accumulated in unsupplemented controls indicates that relatively little of the glucose-derived $\mathrm{H}_{2}$ and formate was linked to methanogenesis. 


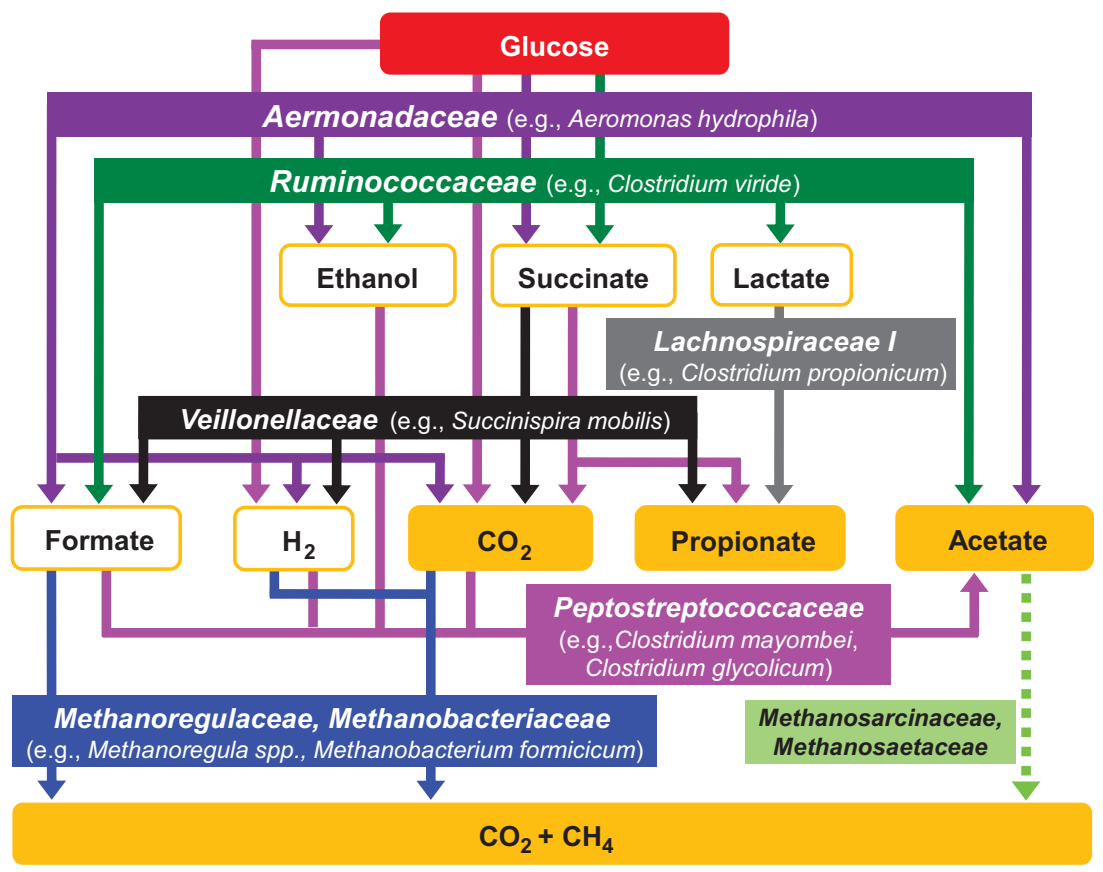

Figure 6 Hypothetical model of the methanogenic food web of the glucose-supplemented gut contents of the $\mathrm{CH}_{4}$-emitting earthworm E. eugeniae. The model is based on detected processes and known functions of the detected taxa. Compounds that accumulated as end products are shown in orange boxes. Species names in brackets represent the closest cultured relatives to retrieved sequences. The dashed light green arrow identifies a potential reaction that was not clearly resolved.

Four molecules of formate are required to synthesize one molecule of acetate via acetogenesis (Drake et al., 2008). Thus approximately $9 \mu \mathrm{mol}$ acetate per gram FW could have been formed from the approximate $34 \mu \mathrm{mol}$ formate per gram FW transiently formed from glucose in $\left[{ }^{13} \mathrm{C}\right]$-glucose treatments. However, because acetate synthesis was continuous during the entire incubation period and far exceeded this value (Figure $3 \mathrm{~d}$ ), it is not possible to accurately correlate the synthesis of acetate via acetogenesis with the consumption of glucose-derived formate. Nonetheless, the occurrence of acetogens in the gut contents was indicated by (a) the detection of sequences in 'heavy' fractions of $\left[{ }^{13} \mathrm{C}\right]$-glucose treatments that were related to the acetogens C. glycolicum (Küsel et al., 2001) and C. mayombei (Kane et al., 1991) and (b) the $\mathrm{H}_{2}$-dependent stimulation of acetate synthesis in methanogenic enrichments. Thus acetate production may have been linked to both fermentation and acetogenesis. C. glycolicum and $C$. mayombei can utilize diverse substrates for acetogenesis, including $\mathrm{H}_{2}-\mathrm{CO}_{2}$, carbohydrates (for example, glucose), alcohols and organic acids (for example, formate) (Kane et al., 1991; Küsel et al., 2001), illustrating the potential of acetogens to facilitate multiple trophic links during the flow of carbon in the gut contents. C. mayombei can also convert succinate to propionate and $\mathrm{CO}_{2}$ (Kane et al., 1991). The capacity of acetogens to utilize a variety of electron donors and electron acceptors (Drake et al., 2008) reinforce the likelihood that acetogens could be metabolically active in the complex milieu of the gut contents of E. eugeniae.

\section{Conclusions}

The collective findings of this study provide the basis for a hypothetical model of the processes and microbial taxa linked to the production of $\mathrm{CH}_{4}$ (Figure 6). Facultative aerobes of the family Aeromonadaceae and obligate anaerobes of the families Lachnospiraceae I, Veillonellaceae and Ruminococcaceae were stimulated by supplemental glucose and are conceived to be representative of taxa involved in the consumption of saccharides in the gut of $E$. eugeniae. Fermentation-derived fatty acids may serve as nutrients for the earthworm under in situ conditions (Wüst et al., 2009a).

Different $\mathrm{H}_{2}$ - and fatty acid-producing fermentations can be spatially distributed along the alimentary canal (Wüst et al., 2009a). Thus methanogenesis might be favored in parts of the alimentary canal where specific physico-chemical conditions favor methanogenesis. Fermentation-derived intermediates such as formate and $\mathrm{H}_{2}$ were likely utilized for methanogenesis by members of the families Methanobacteriaceae and Methanoregulaceae (Figure 6). Although acetoclastic methanogens (for example, Methanosarcinaceae and Methanosaetaceae) were detected, assimilation of glucose-derived acetate by such methanogens was not apparent, and acetate did not appear to stimulate acetoclastic methanogens in the SIP experiment or enrichments. However, it cannot be excluded that acetoclastic methanogens are active in the alimentary canal under in situ conditions.

Glucose was utilized in the present study as a representative saccharide found in the gut contents. 
However, the occurrence of other diverse saccharides such as maltose, mannose, galactose, arabinose and rhamnose in the alimentary canal of earthworms (Wüst et al., 2009a) suggests that the in situ methanogenic food web in the alimentary canal is more complex than that resolved in the present study. In addition, a more in-depth sequencing will be required to gain a more complete understanding of the prokaryotic species-level diversities of the microbial community associated with the methanogenic food web in the alimentary canal. Current studies are focused on the potential effects that different saccharides might have on trophic interactions that drive methanogenesis and on the in situ spatial orientation and regulation of methanogenesis in the alimentary canal of $E$. eugeniae.

\section{Conflict of Interest}

The authors declare no conflict of interest.

\section{Acknowledgements}

We thank Anita S Gößner, Peter S Depkat-Jakob, Oliver Schmidt, Marcus A Horn (University of Bayreuth) and Peter Claus (Max-Planck-Institute for Terrestrial Microbiology) for technical assistance and helpful discussions. Support for this study was provided by the Deutsche Forschungsgemeinschaft (DR310/4-1, DR310/4-2), the University of Bayreuth, Conselho Nacional de Desenvolvimento Científico e Tecnológico (CNPq), Embrapa Florestas, FAPESP (2008/58114-3, 2011/50914-3) and the University of São Paulo.

\section{References}

Altschul SF, Gish W, Miller W, Myers EW, Lipman DJ. (1990). Basic local alignment search tool. J Mol Biol 215: 403-410.

Balch WE, Fox GE, Magrum LJ, Woese CR, Wolfe RS. (1979). Methanogens-re-evaluation of a unique biological group. Microbiol Rev 43: 260-296.

Barois I. (1987). Interactions entre les Vers de Terre (Oligochaeta) tropicaux geophages et la microflore pour l'exploitation de la matiere organique du sol. Travaux des Chercheurs de la Station de Lamto (Côte d'Ivoire) 7: 152-155.

Boone DR, Whitman WB, Rouvière P. (1993). Diversity and taxonomy of methanogens. In: Ferry JG (ed). Methanogenesis. Chapman and Hall: New York, NY, USA, pp 35-80.

Bridgham SD, Cadillo-Quiroz H, Keller JK, Zhuang Q. (2013). Methane emissions from wetlands: biogeochemical, microbial, and modeling perspectives from local to global scales. Glob Chang Biol 19: 1325-1346.

Brown GG, Barois I, Lavelle P. (2000). Regulation of soil organic matter dynamics and microbial activity in the drilosphere and the role of interactions with other edaphic functional domains. Eur J Soil Biol 36: 177-198.
Brown GG, James SW. (2006). Earthworm biodiversity in Sao Paulo state, Brazil. Eur J Soil Biol 42: 145-149.

Brune A. (2006). Symbiotic associations between termites and prokaryotes. In: Dworkin M, Falkow S, Rosenberg E, Schleifer KH, Stackebrandt E (eds). The Prokaryotes, 3rd edn. Springer-Verlag: New York, NY, USA, pp 439-474.

Bräuer SL, Cadillo-Quiroz H, Ward RJ, Yavitt JB, Zinder SH. (2011). Methanoregula boonei gen. nov., sp. nov., an acidiphilic methanogen isolated from an acidic peat bog. Int J Syst Evol Microbiol 61: 45-52.

Buckel W, Janssen PH, Schuhmann A, Eikmanns U, Messner P, Sleytr U et al. (1994). Clostridium viride sp. nov., a strictly anaerobic bacterium using 5-aminovalerate as growth substrate, previously assigned to Clostridium aminovalericum. Arch Microbiol 162: 387-394.

Conrad R, Chan OC, Claus P, Casper P. (2007). Characterization of methanogenic Archaea and stable isotope fractionation during methane production in the profundal sediment of an oligotrophic lake (Lake Stechlin, Germany). Limnol Oceanogr 52: 1393-1406.

Darwin C. (1881). The Formation of Vegetable Mould Through the Action of Worms with Observations on Their Habits. John Murray: London, UK.

Depkat-Jakob PS, Brown GG, Tsai SM, Horn MA, Drake HL. (2013). Emission of nitrous oxide and dinitrogen by diverse earthworm families from Brazil and resolution of associated denitrifying and nitrate-dissimilating taxa. FEMS Microbiol Ecol 83: 375-391.

Depkat-Jakob PS, Hunger S, Schulz K, Brown GG, Tsai SM, Drake HL. (2012). Emission of methane by Eudrilus eugeniae and other earthworms from Brazil. Appl Environ Microbiol 78: 3014-3019.

Dietrich C, Köhler T, Brune A. (2014). The cockroach origin of the termite gut microbiota: patterns in bacterial community structure reflect major evolutionary events. Appl Environ Microbiol 80: 2261-2269.

Domínguez J. (2004). State of the art and new perspectives on vermicomposting research. In: Edwards CA (ed). Earthworm Ecology, 2nd edn CRC Press: Boca Raton, FL, USA, pp 401-424.

Drake HL, Gossner AS, Daniel SL. (2008). Old acetogens, new light. Ann NY Acad Sci 1125: 100-128.

Drake HL, Horn MA. (2007). As the worm turns: the earthworm gut as a transient habitat for soil microbial biomes. Annu Rev Microbiol 61: 169-189.

Edwards CA, Bohlen PJ. (1996). Biology and Ecology of Earthworms vol. 3. Chapman and Hall: London, UK.

Ezaki T. (1984). Genus I. Ruminococcus. In: Krieg NR, Holt JG (eds). Bergy's Manual of Determinative Bacteriology. The Williams and Wilkins Co.: Baltimore, MD, USA, pp 1015-1017.

Ezaki T. (2009). Genus I. Peptostreptococcus. In: De Vos P, Garrity GM, Jones D, Krieg NR, Ludwig W, Rainey FA (eds). Bergey's Manual of Systematic Bacteriology, 2nd edn. Springer: New York, NY, USA, pp 1008-1009.

Felsenstein J. (1985). Confidence limits on phylogenies: an approach using the bootstrap. Evolution 39: 783-791.

Furlong MA, Singleton DR, Coleman DC, Whitman WB. (2002). Molecular and culture-based analyses of prokaryotic communities from an agricultural soil and the burrows and casts of the earthworm Lumbricus rubellus. Appl Environ Microbiol 68: 1265-1279.

Gottschalk G. (1986). Bacterial Metabolism, 2nd edn. Springer: New York, NY, USA. 
Heck KL, Vanbelle G, Simberloff D. (1975). Explicit calculation of rarefaction diversity measurement and determination of sufficient sample size. Ecology 56: 1459-1461.

Hedderich R, Whitman WB. (2006). Physiology and biochemistry of the methane-producing Archaea. In: Falkow S, Rosenberg E, Dworkin M (eds). The Prokaryotes, 3rd edn. Springer: New York, NY, USA, pp 1050-1079.

Hippe H, Andreesen JR, Gottschalk aG. (1992). The genus Clostridium-nonmedical. In: Balows A, Trüper HG, Dworkin M, Harder W, Schleifer K-H (eds). The Prokaryotes, 2nd edn. Springer: New York, NY, USA, pp 1800-1825.

Horn MA, Schramm A, Drake HL. (2003). The earthworm gut: an ideal habitat for ingested $\mathrm{N}_{2} \mathrm{O}$-producing microorganisms. Appl Environ Microbiol 69: 1662-1669.

Hornor SG, Mitchell MJ. (1981). Effect of the earthworm Eisenia foetida (Oligochaeta) on fluxes of volatile carbon and sulfur compounds from sewage sludge. Soil Biol Biochem 13: 367-372.

Hunger S, Schmidt O, Hilgarth M, Horn MA, Kolb S, Conrad R et al. (2011). Competing formate- and carbon dioxide-utilizing prokaryotes in an anoxic methane-emitting fen soil. Appl Environ Microbiol 77: 3773-3785.

Hurlbert SH. (1971). The nonconcept of species diversity: a critique and alternative parameters. Ecology 52: $577-586$

Janssen PH. (1984). Genus XXXIV: Succinispira. In: Krieg NR, Holt JG (eds). Bergy's Manual of Determinative Bacteriology. The Williams and Wilkins Co.: Baltimore, MD, USA, pp 1117-1118.

Kane MD, Brauman A, Breznak JA. (1991). Clostridium mayombei sp. nov., an $\mathrm{H}_{2} / \mathrm{CO}_{2}$ acetogenic bacterium from the gut of the African soil-feeding termite Cubitermes speciosus. Arch Microbiol 156: 99-104.

Karsten GR, Drake HL. (1995). Comparative assessment of the aerobic and anaerobic microfloras of earthworm guts and forest soils. Appl Environ Microbiol 61: 1039-1044.

Karsten GR, Drake HL. (1997). Denitrifying bacteria in the earthworm gastrointestinal tract and in vivo emission of nitrous oxide $\left(\mathrm{N}_{2} \mathrm{O}\right)$ by earthworms. Appl Environ Microbiol 63: 1878-1882.

Knapp B, Podmirseg S, Seeber J, Meyer E, Insam H. (2009). Diet-related composition of the gut microbiota of Lumbricus rubellus as revealed by a molecular fingerprinting technique and cloning. Soil Biol Biochem 41: 2299-2307.

Küsel K, Drake HL. (1995). Effects of environmental parameters on the formation and turnover of acetate by forest soils. Appl Environ Microbiol 61: 3667-3675.

Küsel K, Karnholz A, Trinkwalter T, Devereux R, Acker G, Drake HL. (2001). Physiological ecology of Clostridium glycolicum RD-1, an aerotolerant acetogen isolated from sea grass roots. Appl Environ Microbiol 67: 4734-4741.

Lane DJ. (1991). 16S/23S rRNA sequencing. In: Stackebrandt E, Goodfellow M (eds). Nucleic Acid Techniques in Bacterial Systematics. John Wiley and Sons: Chichester, UK, pp 115-175.

Lavelle P. (1986). Associations mutualistes avec la microflore du sol et richess espécifique SOLIS les tropiques: l'hypothèse du premier maillon. Comptes Rendues de la Acadamie des Sciences de Paris 302: 11-14.
Leaver FW, Wood HG, Stjernholm R. (1955). The fermentation of three carbon substrates by Clostridium propionicum and Propionibacterium. J Bacteriol 70: $521-530$

Lee KE. (1985). Earthworms: Their Ecology and Relationships with Soils and Land Use. Academic Press: Sydney, Australia.

Lottspeich F, Engels J. (2006). Bioanalytik. Spektrum Akademischer Verlag: Heidelberg, Germany.

Lubbers I, Brussaard L, Otten W, Van Groenigen J. (2011). Earthworm-induced $\mathrm{N}$ mineralization in fertilized grassland increases both $\mathrm{N}_{2} \mathrm{O}$ emission and crop-N uptake. Eur J Soil Sci 62: 152-161.

Ludwig W, Strunk O, Westram R, Richter L, Meier H, Yadhukumar A et al. (2004). ARB: a software environment for sequence data. Nucleic Acids Res 32: 1363-1371.

Makeschin F. (1997). Earthworms (Lumbricidae: Oligochaeta): important promoters of soil development and soil fertility. In: Benckiser G (ed.) Fauna in Soil Ecosystems. Marcel Dekker, Inc.: New York, NY, USA, pp 173-223.

Manefield M, Whiteley AS, Griffiths RI, Bailey MJ. (2002). RNA stable isotope probing, a novel means of linking microbial community function to phylogeny. Appl Environ Microbiol 68: 5367-5373.

Martin-Carnahan A, Joseph SW. (2005a). Genus I. Aeromonas. In: Brenner DJ, Krieg NR, Staley JT (eds) Bergey's Manual of Systematic Bacteriology, 2nd edn. Springer: New York, NY, USA, pp 557-578.

Martin-Carnahan A, Joseph SW. (2005b). Aeromonadaceae. Bergey's Manual of Systematic Bacteriology 2: $556-578$.

Martinez AA. (1998). A Grande e Poderosa Minhoca: Manual Prático do Minhocultor, 4th edn. FUNEP: Jaboticabal, Brazil.

Matthies C, Grießhammer A, Schmittroth M, Drake HL. (1999). Evidence for involvement of gut-associated denitrifying bacteria in emission of nitrous oxide $\left(\mathrm{N}_{2} \mathrm{O}\right)$ by earthworms obtained from garden and forest soils. Appl Environ Microbiol 65: 3599-3604.

Mba CC. (1988). Biomass and vermicompost production by the earthworm Eudrilus eugeniae (Kinberg). Rev Biol Trop 37: 11-13.

Morrison M, Pope PB, Denman SE, McSweeney CS. (2009). Plant biomass degradation by gut microbiomes: more of the same or something new? Curr Opin Biotechnol 20: 358-363.

Morrison R. (1984). Family I. Veillonellaceae. In: Krieg NR, Holt JG (eds). Bergy's Manual of Determinative Bacteriology. The Williams and Wilkins Co.: Baltimore, MD, USA.

Nanninga HJ, Gottschal JC. (1985). Amino acid fermentation and hydrogen transfer in mixed cultures. FEMS Microbiol Ecol 31: 261-269.

Nechitaylo TY, Yakimov MM, Godinho M, Timmis KN, Belogolova E, Byzov BA et al. (2010). Effect of the earthworms Lumbricus terrestris and Aporrectodea caliginosa on bacterial diversity in soil. Microb Ecol 59: 574-587.

Oboh BO, Akintobi DO, Ejidereonwu C. (2007). Morphometric studies in Eudrilus eugeniae populations from different locations in Lagos, Nigeria. Nat Sci 5: 16-21.

Pruesse E, Quast C, Knittel K, Fuchs BM, Ludwig W, Peplies J et al. (2007). SILVA: a comprehensive online resource for quality checked and aligned ribosomal RNA sequence data compatible with ARB. Nucleic Acid Res 35: 7188-7196. 
Rizhiya E, Bertora C, van Vliet PC, Kuikman PJ, Faber JH, van Groenigen JW. (2007). Earthworm activity as a determinant for $\mathrm{N}_{2} \mathrm{O}$ emission from crop residue. Soil Biol Biochem 39: 2058-2069.

Saitou N, Nei M. (1987). The neighbor-joining method: a new method for reconstructing phylogenetic trees. Mol Biol Evol 4: 406-425.

Satchell JE. (1967). Lumbricidae. In: Burges A, Raw F (eds). Soil Biology. Academic Press: London, UK, pp 259-322.

Schauer NL, Ferry JG. (1980). Metabolism of formate in Methanobacterium formicicum. J Bacteriol 142: 800-807.

Schloss PD, Handelsman J. (2005). Introducing DOTUR, a computer program for defining operational taxonomic units and estimating species richness. Appl Environ Microbiol 71: 1501-1506.

Schloss PD, Larget BR, Handelsman J. (2004). Integration of microbial ecology and statistics: a test to compare gene libraries. Appl Environ Microbiol 70: 5485-5492.

Schmidt O, Horn MA, Kolb S, Drake HL. (2014). Temperature impacts differentially on the methanogenic food web of cellulose-supplemented peatland soil. Environ Microbiol; doi:10.1111/1462-2920.12507.

Schmidt O, Wüst PK, Hellmuth S, Borst K, Horn MA, Drake HL. (2001). Novel [NiFe]- and [FeFe]-hydrogenase gene transcripts indicative of active facultative aerobes and obligate anaerobes in earthworm gut contents. Appl Environ Microbiol 77: 5842-5850.

Stackebrandt E, Cummins CS, Johnson JL. (2006). Familiy Propionibacteriaceae: the genus Propionibacterium. In: Dworkin M, Falkow S, Rosenberg E, Schleifer K-H, Stackebrandt E (eds). The Prokaryotes, 3rd edn. Springer: New York, NY, USA, pp 400-418.

Šustr V, Šimek M. (2009). Methane release from millipedes and other soil invertebrates in Central Europe. Soil Biol Biochem 41: 1684-1688.

Tamura K, Peterson D, Peterson N, Stecher G, Nei M, Kumar S. (2011). MEGA5: Molecular evolutionary genetics analysis using maximum likelihood, evolutionary distance, and maximum parsimony methods. Mol Biol Evol 28: 2731-2739.

Trigo D, Barois I, Garvin MH, Huertal E, Irisson S. (1999). Mutualism between earthworms and soil microflora. Pedobiologia 43: 866-873.

Wang Q, Garrity GM, Tiedje JM, Cole JR. (2007). Naïve Bayesian classifier for rapid assignment of rRNA sequences into the new bacterial taxonomy. Appl Environ Microbiol 73: 5261-5267.

Whiteley AS, Thomson B, Lueders T, Manefield M. (2007). RNA stable-isotope probing. Nat Protoc 2: 838-844.

Wüst PK, Horn MA, Drake HL. (2009a). In situ hydrogen and nitrous oxide as indicators of concomitant fermentation and denitrification in the alimentary canal of the earthworm Lumbricus terrestris. Appl Environ Microbiol 75: 1852-1859.

Wüst PK, Horn MA, Drake HL. (2011). Clostridiaceae and Enterobacteriaceae as active fermenters in earthworm gut content. ISME J 5: 92-106.

Wüst PK, Horn MA, Henderson G, Janssen PH, Rehm BH, Drake HL. (2009b). Gut-associated denitrification and in vivo emission of nitrous oxide by the earthworm families Megascolecidae and Lumbricidae in New Zealand. Appl Environ Microbiol 75: 3430-3436.

Wüst PK, Horn MA, Henderson G, Janssen PH, Rehm BH, Drake HL. (2009c). Gut-associated denitrification and in vivo emission of nitrous oxide by the earthworm families Megascolecidae and Lumbricidae in New Zealand. Appl Environ Microbiol 75: 3430-3436.

Yarza P, Richter M, Peplies J, Euzeby J, Amann R, Schleifer $\mathrm{KH}$ et al. (2008). The all-species living tree project: A $16 \mathrm{~S}$ rRNA-based phylogenetic tree of all sequenced type strains. Syst Appl Microbiol 31: 241-250.

Yashiro Y, Sakai S, Ehara M, Miyazaki M, Yamaguchi T, Imachi H. (2011). Methanoregula formicica sp. nov., a methane-producing archaeon isolated from methanogenic sludge. Int J Syst Evol Microbiol 61: 53-59.

Zinder SH. (1993). Physiological ecology of methanogens. In: Ferry JG (ed). Methanogenesis. Chapman and Hall: New York, NY, USA, pp 128-206.

Supplementary Information accompanies this paper on The ISME Journal website (http://www.nature.com/ismej) 